\title{
ABUSE OF DOMINANCE IN TEGHNOLOGY- ENABLED MARKETS: ESTABLISHED STANDARDS RECONSIDERED?
}

\author{
MIGUEL RATO AND NICOLAS PETIT*
}

\section{A. Introduction}

This paper seeks to examine whether the legal standards underpinning the application of Article 102 of the Treaty on the Functioning of the European Union (TFEU) need to be revisited in light of the alleged specificities of technology-enabled markets. To this end, the paper is divided into seven parts. Following this short introduction (A), the paper offers first a definition of the very notion of technology-enabled markets (B). It then questions whether competition agencies should depart from conventional enforcement techniques when reviewing conduct in fast-moving, technology-enabled markets, and follow new, expedited enforcement procedures as proposed recently by several highranking officials $(\mathrm{C})$. After this, the paper turns to substantive issues. It begins by reviewing the intricacies of market definition and dominance in technologyenabled markets (D). It then offers some general thoughts on whether a new, general legal standard for the determination of unlawful abuse is needed in technology-enabled markets (E). Finally, the paper considers six categories of abusive conduct in the high-tech sector and shows that, faced with a variety of applicable legal standards for each of them, competition agencies, courts and plaintiffs have - understandably - almost always invoked and applied the loosest possible test in support of their allegations or findings. We suggest, in turn, that under existing case law stricter standards could and should be applied, and that this is particularly important in the context of technology-enabled markets for the simple reason that it is in these markets that the most common pitfalls and shortcomings of the EU law on abuse of a dominant position are magnified (F).

\footnotetext{
Miguel Rato is Partner with Shearman \& Sterling LLP, Brussels. Nicolas Petit is Professor of Law at the University of Liège and Director of the Global Competition Law Centre of the College of Europe (GCLC). The authors are grateful to Norman Neyrinck and Collette Rawnsley for their useful comments on a previous version of the paper. All URLs were last accessed on 15 March 2013.
} 


\section{B. In Search of a Workable Definition of Teghnology-Enabled Markets}

Recent competition law literature is rife with references to a new type of markets which would arguably require specific treatment under the EU competition rules. The labels used to describe these markets vary: high-technology industries, ${ }^{1}$ dynamically competitive industries, ${ }^{2}$ innovative industries, ${ }^{3}$ the digital economy, ${ }^{4}$ the innovation economy, ${ }^{5}$ etc. One common feature of all of these expressions is that they seek to encompass the "new economy," ie sectors as diverse as microprocessors, computer software, online distribution, the internet, etc. Maybe more importantly, another feature common to all of these notions is that, in those industries, technology plays a pivotal role in the competitive process. Hence, in the remainder of this paper, we refer to those markets as "technology-enabled markets".

Against this background, we consider that it is not possible to answer the question whether established legal standards should be reconsidered in technology-enabled markets without first understanding what those markets really are, what they comprise and what makes them special. The first step in our assessment should therefore consist in trying to circumscribe as precisely as possible the notion of a technology-enabled market.

In layman's terms, technology is defined as the use of science for industrial and commercial purposes. Because most markets in today's economy can be said to be technology-enabled, including ageing industries from the nineteenth

1 See J Temple Lang, "European Community Antitrust Law-Innovation Markets and High Technology Industries" (New York, Fordham Corporate Law Institute, 17 October 1996), available at http://ec.europa.eu/competition/speeches/text/sp1996_054_en.html.

2 See D Geradin, C Ahlborn, V Denicolò and J Padilla, "DG Comp's Discussion Paper on Article 82: Implications of the Proposed Framework and Antitrust Rules for Dynamically Competitive Industries" (March 2006), available at http://papers.ssrn.com/sol3/papers. cfm?abstract_id=894466.

3 See R Posner, "Antitrust in the New Economy", Olin Working Paper No 106 (University of Chicago Law \& Economics, November 2000), available at http://ssrn.com/abstract=249316.

4 See J Almunia, "Antitrust Enforcement: Challenges Old and New", SPEECH/12/428, presented at the 19th International Competition Law Forum, St Gallen, 8 June 2012, available at http://europa.eu/rapid/press-release_SPEECH-12-428_en.htm.

5 See F Manjoo, "Apple, Facebook, Google, and Amazon Battle for the Future of the Innovation Economy" (19 October 2011), available at http://www.fastcompany.com/1784824/great-techwar-2012.

6 A 1983 cover article in TIME Magazine described the transition from heavy industry to a new technology-based economy. See C Alexander, A Zagorin and G Bolt, "The New Economy", TIME Magazine, 30 May 1983, available at http://www.time.com/time/magazine/ article/0,9171,926013,00.html. Wikipedia uses the expression "The new economy" to describe the result of the transition from a manufacturing-based economy to a service-based economy. Judge Posner defines the new economy as covering "three distinct though related industries. The first is the manufacture of computer software. The second consists of the internet-based businesses (internet access providers, internet service providers, internet content providers), such as AOL and Amazon. And the third consists of communications services and equipment designed to support the first two markets". See Posner, supra n 3. 
and twentieth centuries such as steel, car manufacturing, defence, chemical products, energy and agriculture, the notion of technology is not particularly helpful in ascertaining the boundaries and key characteristics of the markets we propose to review.

A better approach may thus be to seek to identify, within the existing economic literature, those features which seem most prevalent in such technology-enabled markets. Our conclusion is that a market can be said to be technology enabled if the competitive process is shaped by the presence of most or all of the following features.

First, technology-enabled markets display an intense degree of innovative activity. From an economic standpoint, the importance of innovative activity is generally measured by the magnitude of $R \& D$ activities (eg R\&D expenditure, number of R\&D employees, scientists and engineers, amount of R\&D subsidies obtained from state institutions, etc), by firms' patenting activity (number of patent applications, of patents awarded, of patent citations, etc) and by the sales of new products following the introduction of an invention. ${ }^{7}$ In other words, a key feature of technology-enabled markets is that they are occupied by firms with significant R\&D activities and which rely heavily on the intellectual property (IP) system. The intensity of innovation may also be considered from a quantitative standpoint. ${ }^{8}$ Technology-enabled markets generally display a significant degree of "drastic" innovation - ie innovation that leads to the appearance of new products, eg tablet computers, digital cameras, electrical engines, flat screen TVs, etc. ${ }^{9}$ - in addition to "incremental" innovation-ie innovation that simply improves existing products (by increasing their functionality or decreasing their costs), eg a wireless computer mouse and the embedding of digital cameras in smartphones. ${ }^{10}$

Secondly, the pace of innovation in technology-enabled markets is rapid. In 1965, Gordon Moore, the co-founder of Intel, predicted that computing capacity performance would double every 18-24 months in the following decades. ${ }^{11}$ Whilst Moore's Law has since been proved wrong, his prediction is

See M Kamien and N Schwartz, Market Structure and Innovation (Cambridge University Press, 1982).

8 Those proxies are inherently imperfect. Some important innovations are indeed never patented (eg software). Moreover, major inventions are sometimes introduced by small firms with relatively limited R\&D capacities.

9 Some also refer to this as "breakthrough", "platform" or "disruptive" innovation.

10 Some also refer to this as "sequential" innovation. Interestingly, some business theorists seem to ascribe lower value to "sustaining" technologies, which improve the performance of existing products in the short term, rather than to "disruptive" technologies that threaten the existence of existing technologies in the long term. See C Christensen, R Bohmer and J Kenagy, "Will Disruptive Innovations Cure Health Care?" (2000) 78(5) Harvard Business Review 102, available at https://wiki.umms.med.umich.edu/download/attachments/118335374/disruptive-innovationscure-health.pdf.

11 See G Moore, "Cramming More Components onto Integrated Circuits" (1965) 8 Electronics 82, available at http://download.intel.com/museum/Moores_Law/Articles-Press_Releases/ Gordon_Moore_1965_Article.pdf. 
often cited to illustrate the fact that products have a short life-cycle in technology-enabled markets, and that companies must innovate constantly to remain in the game. In contrast, sectors such as pharmaceuticals, where the life cycle of products is very lengthy, do not belong to the list of technology-enabled markets identified in the above-mentioned literature.

Thirdly, transactions in technology-enabled markets often involve intangible goods, such as ideas, patents, interoperability and design standards, specifications, design protocols, and digital files (eg images, music, videos). ${ }^{12}$ This does not mean, of course, that such markets do not include transactions for tangible goods (eg computers, chipsets); but the main implication is that fixed costs in technology-enabled markets are often constant (there are limited/few capacity constraints for the supply of intangible goods), variable costs are low (intangible goods can be replicated at virtually no cost) and transport costs come close to zero (intangible goods can usually be transmitted across digital communications networks at almost no cost).

Fourthly, technology-enabled markets typically exhibit network effects. The notion of network effects is often linked to Metcalfe's Law, which posits that technologies become more useful as more people use them. ${ }^{13}$ More precisely, network effects arise "when a product is more valuable to a user the more users adopt the same product or compatible ones". ${ }^{14}$ Typical examples of sectors that exhibit network effects include video games, computer operating systems (OS) and social networks. ${ }^{15}$ In certain technology markets, network effects are indirect. This situation occurs when an increase in the number of one category of users (for instance, Facebook subscribers) makes a product more valuable to other categories of users (for instance, firms that display advertisements on Facebook). In such two-sided markets, it is not rare to witness cross-payments between the various categories of users (for instance, Facebook subscribers acquire the service for free, whilst advertisers finance it).

Fifthly, technology-enabled markets are prone to first-mover advantages and winner-takes-all effects. In markets characterised by drastic innovation, the firm that releases a new disruptive product will create a new market in which it will

12 See H Varian, J Farrell and C Shapiro, The Economics of Information Technology (Cambridge University Press, 2004), 7.

13 Metcalfe's Law states that if the value of each user in a network is proportional to the number of other users, then the total value of the network is proportional to the square of the total number of users.

14 See European Commission Glossary, "Network effect", available at http://ec.europa.eu/competition/publications/glossary_en.pdf.

15 On network effects see, eg N Economides, "Network Externalities, Complementarities, and Invitations to Enter" (1996) 2 European Fournal of Political Economy 211; N Economides, "The Economics of Networks" (1996) 6 International fournal of Industrial Organization 673; M Katz and C Shapiro, "Systems Competition and Network Effects" (1994) 2 Fournal of Economic Perspectives 93; A Melamed, "Network Industries and Antitrust"(1999-2000) 23 Harvard Fournal of Law E' Public Policy 147. 
often enjoy a durable leadership - or even a monopolistic position - until other firms adapt and enter the new market. ${ }^{16}$ Importantly, because the first mover will service the entire market demand, at least for some period of time, it may benefit from economies of scale that new entrants will not be able to replicate at least in the short term. This incumbency advantage of the first mover may be further magnified if the invention in question is protected by intellectual property rights (IPR) and if the market is subject to network effects, etc.

Sixthly, technology-enabled markets often display significant price and product differentiation because technology makes it exponentially easier for suppliers to charge customised prices for similar goods and services on the basis of customer behaviour, characteristics, location, etc.

Seventhly, standard-setting activities, which aim to achieve device interoperability and product compatibility, play a fundamental role in technology-enabled markets. For instance, a modern laptop computer embodies or utilises at least 251 interoperability standards. ${ }^{17}$

Finally, technology-enabled markets are often deemed to exhibit switching costs and, in turn, to give rise to lock-in effects. ${ }^{18}$ The idea is as follows: users of technology-enabled products that contemplate changing suppliers will often be discouraged from switching because this will entail all sorts of costs (not only in financial terms, but also in terms of loss of time, convenience, etc). For instance, a consumer who changes computers and acquires a device running a different OS may have to modify document formats, purchase and become familiar with new application software, etc. He will also have to get acquainted with a new product. Similarly, companies wishing to change software environments will often have to hire consultants, retrain their professional force, shut their daily activities for some days, etc. ${ }^{19}$ In certain circumstances, those costs can be so high that it would be unthinkable for customers to change suppliers. ${ }^{20}$

Competition authorities often tend to view switching costs as an endemic feature of technology-enabled markets. ${ }^{21}$ In turn, they often seem eager to infer

16 Sometimes, the disruptive firm merely creates a new market segment.

17 See B Biddle, A White and S Woods, "How Many Standards in a Laptop? (And Other Empirical Questions)", available at http://standardslaw.org/How_Many_Standards.pdf.

18 On these notions, see P Klemperer, "Markets with Consumer Switching Costs" (1987) 2 The Quarterly Fournal of Economics 375; P Klemperer, "The Competitiveness of Markets with Switching Costs" (1987) 1 The RAND Fournal of Economics 138; J Farrell and C Shaprio, "Dynamic Competition with Switching Costs" (1988) 1 The RAND Journal of Economics 123; P Klemperer, "Competition when Consumers have Switching Costs: An Overview with Applications to Industrial Organization, Macroeconomics, and International Trade" (1995) 4 Review of Economic Studies 515; B Garcia Mariñoso, "Technological Incompatibility, Endogenous Switching Costs and Lock-in" (2001) 3 The Fournal of Industrial Economics 281.

19 On top of those costs, "hassle costs" and possible status quo biases may further increase inelasticity on the demand side. See, eg M Hviid and G Shaffer, "Hassle Costs: The Achilles' Heel of Price-Matching Guarantees" (1999) 4 Journal of Economics E Management Strategy 489.

20 See Varian et al, supra n 12, 21.

21 Ibid. 
that competition in those markets is suboptimal. In our opinion, however, such a broad assumption would be incorrect. Switching costs are not specific to technology-enabled markets. In fact, they can be observed in many other markets (eg retail banking, air transport, legal services). Moreover, switching costs are absent from many markets that can be qualified as technology-enabled. For instance, users incur little cost when they switch printers, digital cameras, etc. Even on the particular subset of software and in internet markets, where switching costs are allegedly widespread and significant, their occurrence and magnitude appear overestimated. To take the example of the information and communications technology (ICT) sector, the fact that many software products are given away for free, that competition is often just "one click away"22 (eg on software downloading platforms) and that storage capacities are unlimited means that users can easily switch to more efficient sources of supply. The rapid erosion of Microsoft's Internet Explorer browser's market share following the entry of Mozilla Firefox into the web browser's market is a good illustration of this phenomenon.

That said, and despite these reservations, we include switching costs in our list of features of technology-enabled markets so as to provide a full account of the academic literature on this issue.

\section{G. Is a New Enforgement Approagh Warranted in Teghnology-enabled Markets?}

Technology markets are fast moving. This creates a challenge for antitrust agencies, whose traditional enforcement procedures are generally slow and cumbersome: antitrust proceedings habitually span several years. In Microsoft $I,{ }^{23}$ for instance, Sun Microsystems lodged a complaint in 1998 and it took over 10 years for the Commission to administer remedies. Similarly, in Intel, ${ }^{24}$ nine years elapsed between AMD's complaint and the Commission's infringement decision.

Against this background, it will come as no surprise that commentators (and many agency officials) have advocated new, swifter, enforcement procedures in fast-moving markets. In two recent speeches, Commissioner Almunia hinted that he would not wait until push comes to shove. In fast-moving markets, he said, "restoring competition swiftly to the benefit of users at an early stage is always

22 See A Kovacevicj, "Google's Approach to Competition”, Google Public Policy Blog, 8 May 2009, available at http://googlepublicpolicy.blogspot.be/2009/05/googles-approach-to-competition. html.

23 See Microsoft [2007] OJ L32/23.

24 See Intel [2009] OJ C227/13. 
preferable to lengthy proceedings". ${ }^{25}$ Shortly thereafter, the Commissioner put theory to practice, with the unprecedented move of publicly requesting commitments from Google under threat of issuing a Statement of Objections. ${ }^{26}$

Although it seems fairly abstract at this stage, the Commissioner's proposed new approach appears to have two manifest features. First, the Commission seems convinced that in fast-moving markets, anticompetitive exclusion can take place in a matter of days. An ex ante approach would thus be required to prevent harm. From a technical standpoint, this means that antitrust agencies would have to intervene before the occurrence of actual anticompetitive effects, as soon as there is a risk of likely anticompetitive effects.

Secondly, the Commissioner's proposal suggests that the long and tortuous procedural route of standard antitrust proceedings should be avoided. High-tech cases should be dealt with under faster mechanisms, such as interim measures or Article 9 settlements. ${ }^{27}$ As the Commissioner himself stated: "the companies concerned [must be] ready to seriously address and solve the problems at stake". ${ }^{28}$ This method has the advantage that the Commission does not have to formally prove a competition law infringement. In addition, it would allow the Commission to secure behavioural and structural remedies as extensive, if not more so, than those it would be able to secure relying on traditional enforcement proceedings. Finally, when the Commission applies remedies through this method, it does not need to pass the demanding "proportionality" test, and it is close to immune from judicial challenge by the parties in question.

On closer analysis, the Commissioner's proposed new approach appears similar to sector-specific regulatory mechanisms, such as those applied in network industries: intervention takes place ex ante, ideally before the occurrence of actual anticompetitive effects, due process safeguards are kept to a minimum, intrusive remedies are imposed, there are no fines, etc. The only clear difference with sector specific regulation is perhaps that the Commissioner's proposed process is more collaborative (see Table I). All in all, however, the Commission seems to be casting an envious eye at the working methods and powers of sectoral regulators.

Whilst, at first blush, it appears commendable - the mantra that fast-moving markets need swift antitrust oversight seems to make sense - the Commissioner's proposed approach would, in our view, constitute an unsound, and unlawful,

25 See J Almunia, "Statement of Vice-President Almunia on the Google Antitrust Investigation", SPEECH/12/372 (Brussels, 21 May 2012), available at http://europa.eu/rapid/pressReleasesAction.do? reference=SPEECH/12/372; Almunia, supra $\mathrm{n} 4$.

26 "Statement of Vice-President Almunia", ibid, a request which is arguably devoid of legal basis and of binding effects. The fact that Google responded to it may either have to do with Google's well-known settlement culture or with the willingness to benefit from mitigating circumstances, should fines ever be imposed at a later stage.

27 See Council Regulation (EC) No 1/2003 of 16 December 2002 on the implementation of the rules on competition laid down in Articles [101 and 102] of the Treaty, [2003] OJ L1/1.

28 See Almunia, supra n 4. 
Table I: Comparison of the Proposed Enforcement Approach for High-Tech Markets with SSR and Antitrust Enforcement

\begin{tabular}{|c|c|c|}
\hline Sector-specific regulation & $\begin{array}{l}\text { Proposed approach for high- } \\
\text { tech industries }\end{array}$ & Classic antitrust approach \\
\hline Ex ante & Ex ante & Ex post \\
\hline $\begin{array}{l}\text { No proof of anticompetitive } \\
\text { object/effects }\end{array}$ & $\begin{array}{l}\text { No proof of antitrust offence } \\
\text { (serious concerns, even before } \\
\text { SO) }\end{array}$ & $\begin{array}{l}\text { Proof of antitrust offence (anti- } \\
\text { competitive object/effect) }\end{array}$ \\
\hline Remedies & Commitments & Remedies/fines \\
\hline $\begin{array}{l}\text { Minimal due process require- } \\
\text { ments }\end{array}$ & $\begin{array}{l}\text { Minimal due process require- } \\
\text { ments }\end{array}$ & $\begin{array}{l}\text { Heavy due process require- } \\
\text { ments }\end{array}$ \\
\hline No fault & No fault & Fault \\
\hline Ongoing monitoring & $\begin{array}{l}\text { Ongoing monitoring of com- } \\
\text { mitments }\end{array}$ & One shot \\
\hline Injunctive & $\begin{array}{l}\text { Hybrid (settlement, but com- } \\
\text { mitments are mandatory) }\end{array}$ & Injunctive or collaborative \\
\hline
\end{tabular}

expansion of the mandate of EU competition law far beyond its remit. In network industries the adoption, through sector-specific legislation, of heavyhanded ex ante remedies that go far beyond what would be possible through the traditional application of competition rules results from two assumptions, neither of which are necessarily present in high-tech markets.

The first of these assumptions is that network industries are characterised by the presence of insurmountable barriers to entry. However, in many technology-enabled markets, barriers to entry are low. Unlike in network industries, where incumbents' dominance translates into permanence, incumbents in fastmoving markets are often giants with feet of clay. The history of technology abounds with examples of defeated monopolists. Think of the demise of Kodak, a well-known monopolist of the twentieth century, or of famous web portals such as AOL, Yahoo! and MySpace, or of the current predicaments of once-mighty mobile handset makers such as Motorola and Nokia.

The second of these assumptions is that the risk of anticompetitive effects is very high in network industries. Here again, however, it is far from clear that this risk will be present in technology-enabled markets. It is true that the key features of competition in fast-moving technology markets often leads to the emergence of firms with many of the classic outward signs of a monopolist: very high market shares, aggressive market behaviour and significant profit margins. Yet these elements should not be mistaken for undeniable proof of the existence of significant market power or, more importantly, of unlawful anticompetitive conduct. Large market shares are often ephemeral; high profit margins not only represent the necessary reward for substantial risk-taking, but are also often due to specificities in cost structures and, in particular, to 
increasing returns to scale; and what appears to be aggressive conduct may in fact constitute a novel commercial strategy which does not fall squarely within existing standards of per se legality.

The upshot of this is that the traditional identification problem ${ }^{29}$ encountered in the application of Article 102 is compounded in technology-enabled markets. It is often harder in high-tech industries to separate the wheat of competition on the merits from the chaff of anticompetitive behaviour. ${ }^{30}$ Put differently, technology-enabled markets may be more prone to decisional errors, especially if the preventive ex ante approach advocated by the Commission of late were to be followed.

More importantly, the consequences of getting it wrong - ie intervening to curb competitive behaviour - are likely to be far more severe in technologyenabled markets than in other industries. This is so for at least three reasons.

First, as explained by Professor Varian, ${ }^{31}$ these markets are often "combinatorial", meaning that they draw on distinct technologies "whose rich set of components can be combined and recombined to create new products". Those markets have the potential to generate multiple innovations across diverse economic sectors, as the developers of technology products run through the myriad possibilities available to them. ${ }^{32}$ The development of the gasoline engine, which was incorporated into and combined with a variety of products, including cars, boats, generators, etc, is a typical example of combined innovation.

29 The identification problem refers to the fundamental question of determining what is legal or illegal behaviour under competition law. Michele Polo, suggests a two steps methodology to solve the question:

"The most compelling task in the application of Article 82 rests on the need to distinguish unilateral practices aimed at foreclosing the market from conducts that characterize competition in an oligopolistic environment. The legal rule, indeed, prohibiting the abuse of a dominant position, is intended to prevent the former without placing too many restrictions on oligopolistic competition. The enforcer should try to prevent abuses without chilling competition on the merits ... In this perspective, I argue that the correct evaluation of a given episode requires a double task. First, I need to carefully specify the kind of anticompetitive story I have in mind . . . As the second step, I need to analyse the characteristics of the market environment and the mode of competition that would better fit the case when no anticompetitive strategy is in place . . The anticompetitive and competitive stories must be spelt out in detail, selecting from the economic analysis the explanations (models) that best fit the market environment and the firms' characteristics. This way, I can obtain two sets of empirical predictions, some of which may be common in the two stories and others that occur only in one of them. These latter factual elements are those that allow for identifying the proper explanation."

M Polo, "Anticompetitive vs Competitive Explanations of Unilateral Practices: the Identification Problem" (2010) 6(2) Journal of Competition Law \& Economics 458, 474. See also W Kovacic, "Identification and Proof of Horizontal Agreements under the Antitrust Laws" (1993) 38 Antitrust Bulletin 5.

30 Beyond abuse of dominance, this identification problem exists in many other areas of competition law, and more generally of economics (eg in econometrics).

31 See Varian et al, supra n 12, 5.

32 See C Shapiro and H Varian, Information Rules: A Strategic Guide to the Network Economy (Harvard Business Press, 1999), 5. 
Similarly, the internet, which was initially designed for point-to-point computer communication in the military sector, has subsequently spawned a myriad of new applications through its combination with technologies as diverse as fixed and mobile telephony, television, music, gaming and optical imaging, with new applications being created on a daily basis. As a result, antitrust intervention in respect of one component may have unintended (and detrimental) consequences for one or more related and interdependent components.

Secondly, curtailing the rewards available to market leaders in technologyenabled markets through antitrust intervention will reduce the incentives to innovate not only for the alleged infringer but also for innovators more generally. By their very nature, these markets generally lack legal precedents and, as such, any decision enforcing the competition rules against innovative types of conduct will typically become the yardstick against which other innovators will assess the lawfulness of their commercial strategies and investors will gauge the risk inherent in directing resources to other technologies. ${ }^{33}$

Thirdly, the negative consequences of over-enforcement will be more pronounced in technology-enabled markets, in particular in information and communications technologies, than in other markets. This is because those markets are deemed to be the key drivers of growth in modern, knowledgebased economies. ${ }^{34}$

In our view, all this casts doubt on the desirability of the Commissioner's proposals for a new approach to enforcement in fast-moving markets. Interestingly, other Commission services have explicitly stated that ex ante sector-specific regulatory mechanisms were ill-suited to (newly) emerging markets. For example, in its Communication on relevant markets in electronic communications, the Commission stated that:

"Newly emerging markets should not be subject to inappropriate obligations, even if there is a first mover advantage . . . Newly emerging markets are considered to comprise products or services, where, due to their novelty, it is very difficult to predict demand conditions or market entry and supply conditions, and consequently difficult to apply the three criteria. The purpose of not subjecting newly emerging markets to inappropriate obligations is to promote innovation ...".35

33 Of course, some may argue that this approach would have the merit of allowing the Commission to provide timely guidance to market participants. This argument is not persuasive simply because Art 9 commitment decisions hardly provide any guidance to market participants. In addition, if the Commission really wishes to provide guidance it has other, less burdensome instruments at its disposal (eg guidelines, guidance letters).

34 See Conclusions of the European Council of 17 June 2010 adopting the "Europe 2020" strategy for growth (EUCO 13/10 CO EUR 9 CONCL 2). See also "Communication from the Commission, Europe 2020, A Strategy for Smart, Sustainable and Inclusive Growth", COM(2010) 2020 final.

35 See Commission Recommendation of 17 December 2007 on relevant product and service markets within the electronic communications sector susceptible to ex ante regulation in 




Fig 1 Admissibility of Antitrust Enforcement in Slow and Fast-Moving Markets

\section{Market Definition and Dominance in Teghnology-enabled Markets}

Against this background, we now turn to substantive issues. Before dealing with the notion of abuse, this section focuses on market definition and dominance. More specifically, it takes a closer look at several misconceptions about dominance that often vitiate the competitive assessment of conduct in technology-enabled markets. ${ }^{36}$

\section{Inadequacy of Static Market Share Analysis}

Under current enforcement standards, a strong, and some would say excessive, emphasis is placed on market shares for the purposes of establishing dominance. ${ }^{37}$ This focus on market shares is even less appropriate when it comes to technology-enabled markets, where it is often the case that, within a very short time period, a firm hitherto seen as the dominant market player will

accordance with Directive 2002/21/EC of the European Parliament and of the Council on a common regulatory framework for electronic communications networks and services [2007] OJ L344/65, para 7.

36 On the analysis of dynamic markets in general see G Sidak and D Teece, "Dynamic Competition in Antitrust Law" (2009) 4 Journal of Competition Law Eै Economics 581; D Gifford and R Kudrle, "Antitrust Approaches to Dynamically Competitive Industries in the United States and the European Union" (2011) 3 Journal of Competition Law \& Economics 695.

37 See Case C-62/86 AKZO Chemie BV v Commission [1991] ECR I-3359, para 60: "Save in exceptional circumstances, very large market shares are in themselves evidence of the existence of a dominant position. That is the case where there is a market share of $50 \%$ ". 
see its market share evaporate and be demoted to an also-ran. As seen above, the history of technology markets abounds with examples of extremely rapid shifts in market shares.

\section{High Profit Margins Are Not in Themselves Indicative of Significant Market Power}

As discussed above, because market shares in the technology field are fickle, the fact that the market leaders will usually enjoy very high profit margins should not be seen as conclusive evidence of the existence of market power. In conventional antitrust analysis, the existence of a dominant position implies the ability to reap supracompetitive profits over an extended period of time. This is evident in the SSNIP test, which in essence measures a firm's ability to increase prices on a non-transitory basis. Likewise, the Commission takes the view that market entry by potential competitors can be considered sufficiently swift to deter or defeat the exercise of market power where it is likely to occur within the space of two years. ${ }^{38}$

\section{Prevalence of Competitive Constraints Arising from the Complementary Nature of Technological Components}

By their very nature, most technological products are complements of other such products. Hardware components must connect to other hardware components, software programs must be able to communicate with each other, devices are frequently required to interoperate/be interoperable. From a competition law standpoint, this means that the pricing freedom of a supplier of technology is often constrained by the pricing policies of suppliers of complementary technology. ${ }^{39}$ In its 1976 United Brands judgment, the European Court of Justice (ECJ) famously defined a dominant position as

"a position of economic strength enjoyed by an undertaking which enables it to prevent effective competition being maintained on the relevant market by affording it the power to behave to an appreciable extent independently of its competitors, customers and ultimately of its consumers." ${ }^{\prime 40}$

38 See Guidelines on the assessment of horizontal mergers under the Council Regulation on the control of concentrations between undertakings [2004] OJ C31/5, para 74.

39 On the internal constraints exercised by suppliers of complements see D Geradin and M Rato, "Can Standard-Setting Lead to Exploitative Abuse? A Dissonant View on Patent Hold-Up, Royalty-Stacking and the Meaning of FRAND" (2007) 3 European Competition fournal 146; A Layne-Farrar, "Nondiscriminatory Pricing: Is Standard Setting Different? (2010) 4 Fournal of Competition Law \& Economics 811; B Kobayashi and J Wright, "Intellectual Property and Standard Setting", ABA Handbook on the Antitrust Aspects of Standards Setting, 2010, George Mason Law \& Economics Research Paper No 09-40 (August 2009), available at http://papers.ssrn. com/sol3/papers.cfm?abstract_id=1460997.

40 See Case 26/76 United Brands v Commission [1978] ECR 207. On this issue see, eg P Akman and L Garrod, "When Are Excessive Prices Unfair?" (2011) 7(2) Fournal of Competition Law 
Inevitably, this definition did not, and could not, foresee the increasing competitive constraints represented by technological complements. However, where the commercial success of a given technology and the competitiveness of other such technologies are interdependent, the requirement that the allegedly dominant firm must have the power to behave independently is unlikely to be met.

\section{Technological Gonvergence Greates Substantial Competitive Constraints across Relevant Markets-Demand Side (1)}

As technologies evolve, products which had hitherto satisfied distinct customer needs come to be seen as substitutes by an increasing number of users. Examples of this process include the evolving relationship between laptop computers, tablets, smartphones and personal digital assistants. In many cases, as a result of that technological convergence, ${ }^{41}$ a firm occupying a dominant position in one relevant market will inevitably be dragged towards one or more adjacent markets, where it will face competition from one or more dominant firms. ${ }^{42}$

\section{Technological Gonvergence Greates Substantial Competitive Constraints across Relevant Markets-Supply Side (2)}

The conventional framework for defining relevant markets is often inadequate to assess competitive dynamics in technology-enabled markets. In traditional antitrust analysis, competition authorities generally pay little attention to potential competition. ${ }^{43}$ However, in technology-enabled markets, the degree of potential competition posed by/arising from distinct technologies disciplines the existing technologies through the threat of replacement over time

Eै Economics 403; L Hou, "Excessive Prices within EU Competition Law" (2011) 7 European Competition fournal 47.

41 In 1997, the European Commission issued a "Green Paper on the Convergence of the Telecommunications, Media and Information Technology Sectors, and the Implications for Regulation" $(\mathrm{COM}(97) 623,1)$, where it is stated that:

"'the term convergence eludes precise definition, but is most commonly expressed as: The ability of different network platforms to carry essentially similar kinds of services [for instance telephony not only on traditional telephone networks but also on cable TV networks], or the coming together of consumer devises such as the telephone, television and personal computer' [for instance advanced mobile terminals for both telephony, computing and with broadcast receivers]."

42 "Market dynamics may for instance be caused by technological developments, or by the convergence of products and markets which may give rise to competitive constraints being exercised between operators active in distinct product markets." See Commission Recommendation of 17 December 2007, supra n 35, para 12.

43 On potential competition see, eg P Dasgupta and J Stiglitz, "Potential Competition, Actual Competition, and Economic Welfare" (1988) 32(2-3) European Economic Review 569; R Gilbert, "The Role of Potential Competition in Industrial Organization" (1989) 3 The Fournal of Economic Perspectives 107; D Bush and S Massa, "Rethinking the Potential Competition Doctrine" [2004] Wisconsin Law Review 1035. 
(eg laptops v tablet computers). This is because potential competitors are often able to enter existing markets and threaten incumbent technologies in a very short period of time. This is particularly the case with intangible goods, in respect of which none of the physical constraints of the traditional bricks-andmortar economy - such as capacity constraints or the availability of physical inputs - are present. For instance, Microsoft Word and its rivals faced potential competition from a number of other software developers before that competition became actual (in tangible form), for instance from Google Docs. Now Microsoft is poised to make a large range of its word application software available on the internet for free. ${ }^{44}$ In practice, this means that agencies and courts should scrutinise potential competition from the very outset and include in their analysis of the relevant market all those technologies that may replace, be integrated or converge with the technological product or service in question. This could, in certain cases, lead courts and authorities to define markets as wide as a given technological sector.

\section{The Road to Dominance May Matter}

It is well established that dominance is an objective concept, and thus that the manner in which it was acquired should be of no concern in an antitrust analysis. ${ }^{45}$ But should this always be the case, especially in circumstances where, as often occurs in technology-enabled markets, most - if not all-competition takes place ex ante for the market as opposed to ex post in the market? Not unlike what happens in the conventional antitrust analysis of bidding markets, a case could be made that, if vigorous competition has taken place ex ante, then the market position of the allegedly dominant firm is nothing but a competitive outcome. This should prevent a finding of dominance, and the emergence of the ensuing special responsibility borne by dominant firms.

\section{IP Rights Do Not Necessarily Confer Significant Market Power}

Competition law textbooks often state that IPR confer a monopoly on their owners. ${ }^{46}$ This assertion may have led generations of students to hold the

44 See R Waters, "Microsoft Office Set to Go Free Online", Financial Times, 10 June 2010, available at http://www.ft.com/cms/s/2/c836d258-74bc-11df-aed7-00144feabdc0.html\#axzzlzMdoVbJQ.

45 See Case 85/76 Hoffmann-La Roche \& Co AG v Commission [1979] ECR 461, para 91.

46 The Court of Justice itself also sometimes makes similar approximations. See Joined Cases C-468/06 to C-478/06 Sot Lélos kai Sia EE and Others v GlaxoSmithKline AEVE[2008] ECR I-7139, para 64:

"a medicine is protected by a patent which confers a temporary monopoly on its holder, the price competition which may exist between a producer and its distributors, or between parallel traders and national distributors, is, until the expiry of that patent, the only form of competition which can be envisaged". 
mistaken belief that the monopoly in question was akin to a monopoly position in the antitrust sense. That is not the case: just as with tangible property rights, intangible IPR does indeed confer a legal monopoly on its owner; this monopoly over IPR is therefore no different from one's monopoly over tangible goods, which cannot be consumed by others without the owner's consent. Yet this in no way endows the apparent legal monopolist with significant market power in the economic sense. As the case may be, those others will find alternative sources of supply in the market place, and will be able to purchase, rent, own and even borrow tangible goods from other legal monopolists. The same holds true for IPR in technology-enabled markets: the inventions they protect will often compete with substitutable inventions, which may or may not also be protected by similar legal monopolies conferred by IPR.

\section{Standards $(1)$}

Over the last few years, the cooperative creation of technology standards within formal or looser standardisation bodies, ${ }^{47}$ as well as the emergence of de facto standards ${ }^{48}$ has proved fertile ground for Article 102 claims and investigations. In this context, some have equated the ownership of IPR incorporated in such standards with the enjoyment of a dominant position, ${ }^{49}$ or have come close to doing so. ${ }^{50}$

Such a presumption is incorrect. First, many standards face competition not only from other standards, ${ }^{51}$ but also from non-standardised solutions. Secondly, all technology standards - including de facto standards - can be subject to potential competition from new standards and new non-standardised solutions, which, in the technology realm, are often quickly adopted and may

47 Which define the technical or quality requirements with which current or future products, production processes, services or methods may comply. See Communication from the Commission - Guidelines on the applicability of Article 101 of the Treaty on the Functioning of the European Union to horizontal co-operation agreements [2011] OJ C11/1 (hereinafter HCG), para 257.

48 See Microsoft, supra 23, 23-28.

49 See P Chappatte, "FRAND Commitments - The Case for Antitrust Intervention" (2009) 5 European Competition fournal 319; M Dolmans, "Standards, IP, and Competition: How to Avoid False FRANDs", Fordham IP Law Institute, "Standard Setting-The Interplay with IP and Competition Laws", paper presented at the 2008 Fordham IPR Conference, 12-13; German Federal Supreme Court, Judgment of 6 May 2009, Orange Book Standard, KZR 39/06.

50 See Case M.6381 Google/Motorola Mobility [2012] OJ C75/1, para 61:

"The Commission considers that each SEP can be considered as a separate market in itself as it is necessary to comply with a standard and thus cannot be designed around, ie. there is by definition no alternative or substitute for each such patent".

51 "Certainly some standards do face competition from other cooperative efforts centered on different technological solutions for the same or largely similar issues". See D Geradin, A Layne-Farrar and J Padilla, "The Ex Ante Auction Model for the Control of Market Power in Standard Setting Organizations" (2007), 13, available at http://papers.ssrn.com/sol3/papers. cfm?abstract_id=979393. 
gain immediate market traction. Thirdly, owners of standard-essential IPR are constrained by the repeated-game nature of formal standard-setting: if they exercise market power with regard to one standardised technology, they risk being punished by standard-setting participants in future generations of the same standard or in standard-setting efforts for the creation of entirely distinct technology standards. ${ }^{52}$ Fourthly, owners of standard-essential IPR are very frequently constrained by the need to obtain access to IPR essential to the same or another standard from other IPR owners. ${ }^{53}$ In such cases, it would be illogical to consider that one such essential IPR owner would be in a dominant position vis-à-vis that counterpart. One cannot be dominant and "dominated" at the same time within one and the same business relationship.

\section{Standards (2)}

Another common misconception relates to the potential relevance, from an antitrust standpoint, of the supposed dichotomy between open and proprietary standards. It is frequently argued that open standards confer little market power whilst, by contrast, proprietary standards give standards owners the power to exclude. Again, this is not necessarily the case: many proprietary standards are open, ${ }^{54}$ meaning that they can be implemented by any interested third-partyin some instances, royalty-free.

\section{E. General Reflections on Legal Standards for Unlawful Abuse in Teghnology-enabled Markets}

This section focuses on the fundamental question of whether the substantive law on abuse of dominance should be applied directly to technology-enabled markets or whether it should be modified/tempered to take account of the specific features of such markets. In our view, the answer to this question is that there should not be a specific substantive law on abuse for technology enabled markets. In contrast to the views expressed by (some) other commentators, ${ }^{55}$ we consider that tailoring general legal standards to fit different economic sectors or evolving market contexts is inappropriate. It undermines legal certainty and creates the potential for arbitrary decisions and bad law.

52 See Geradin and Rato, supra n 39, $146 \mathrm{ff}$.

53 See D Geradin and M Rato, "FRAND Commitments and EC Competition Law: A Reply to Philippe Chappatte" (2010) 1 European Competition fournal 136.

54 For example, the MPEG-2, DVD-Video, CD-ROM and DVD-ROM standards are open standards. On open standards see, eg M Glader, "Open Standards: Public Policy Aspects and Competition Law Requirements" (2010) 6 European Competition Fournal 611.

55 See Geradin et al, supra $\mathrm{n} 2$. 
In our view, it is the application of Article 102 itself that requires an overhaul to finally move it from the resilient, unsatisfactory form-based analysis of its early days to the much heralded, yet rarely implemented, effects-based approach. This need for change is particularly acute for technology-enabled markets because form-based legal standards (which infer likely anticompetitive effects from the form of a type of conduct under analysis) are unlikely to be applicable or relevant to the novel types of conduct prevalent in technology markets, where the emergence of such effects is, at best, uncertain.

The constant stream of Article 102 complaints whereby high-tech firms accuse each other of myriad abuses (and of enjoying myriad dominant positions) illustrates how inadequate, legally uncertain and economically nonsensical the current legal standards on abuse of dominance have become. One only has to consider the headline-grabbing commercial disputes pitting Google v Apple v Samsung v Microsoft v Motorola v Apple v Nokia v Microsoft v Google currently making its way through various antitrust agencies and the European Commission and a number of courts throughout the world to understand that the status quo is unsatisfactory, and that the "it's not me, it's you" rhetoric at play clearly suggests that existing Article 102 standards are inadequate and/ or inappropriate. With a little imagination - and significant financial resources (which are clearly at the disposal of the above-mentioned complainants)anything can be alleged and argued, because the legal standards are loose, undemanding and remarkably elastic. In turn, one cannot exclude that, faced with a stack of complex, data-intensive cases, the Commission may be unable to/prevented from taking any significant enforcement initiatives (leading to a false-negative or type II error). Those who believe in conspiracy theories could even suspect the complainants of jointly trying to "trap" the agency, ${ }^{56}$ by clogging it up with an unmanageable number of complaints - a strategy made easier under the current form-based enforcement standards.

Against this background, we consider that the form-based analysis to which the European Courts continue to cling (for instance, in the Tomra ruling ${ }^{57}$ ) must finally be abandoned in favour of more refined and more accurate (and appropriate) legal standards based on theories of harm and instruments that reflect widely accepted contemporary legal and economic antitrust thinking. ${ }^{58}$ Whilst

56 See M Schinkel, "Market Oversight Games", Amsterdam Center for Law \& Economics Working Paper No 2010-11, available at http://papers.ssrn.com/sol3/papers.cfm?abstract_id=1692733.

57 See Case C-549/10P Tomra Systems ASA and Others v European Commission, Judgment of 19 April 2012, not yet reported; Case T-155/06 Tomra Systems ASA and Others v European Commission [2010] ECR II-4361.

58 For a US view on this see T Lipsky, "Antitrust Economics-Making Progress, Avoiding Regression"(2003) 1 George Mason Law Review 167, available at http://www.lw.com/upload/ pubContent/_pdf/pub3990_1.pdf:

"there is no longer any serious debate in U.S. antitrust that policies and rules must be formulated in terms of their ultimate effect on long-run economic performance - whether 
it is true that some aspects of competition law and economics remain subject to debate, it is no less true that the cornerstones of the discipline lay on solid, consensual ground. With this in mind, several best practices can be formulated in relation to the concept of abuse not only in technology-enabled markets, but also more generally.

First, agencies and courts should focus on exclusionary conduct as a matter of priority, and treat allegations of unlawful exploitative abuse as second-order priorities. This is actually in the approach advocated by the Commission itself in its "Guidance on its Enforcement Priorities in Applying Article 82 of the EG Treaty to Abusive Exclusionary Conduct by Dominant Undertakings" (Guidance Paper), which is yet to be applied in practice, and from a theoretical standpoint this position is the necessary logical implication of the fact that to condemn a firm for charging excessive prices is equivalent to condemning dominance itself. Of course, we know all too well that, unlike agencies, courts do not in principle have the ability to discriminate between cases and assign to them distinct degrees of priority. However, the European Courts' case law makes it very clear that prices will only be found to be excessive in exceptional circumstances, where structural obstacles (eg barriers to entry, exclusive or special rights) are close to insurmountable. Moreover, from a practical standpoint, the second limb of the United Brands ${ }^{59}$ test - which requires a comparison between the prices charged by the dominant firm and the prices of competing products over time - would in all likelihood constitute a difficult obstacle to overcome for excessive pricing complaints in technology-enabled markets where such comparators will be ex hypothesi absent.

Secondly, with regard to allegations of exclusionary behaviour, legal standards requiring proof of anticompetitive effects should replace, without exception, those legal standards with a lower evidentiary burden based on the form or type of conduct under consideration. For the avoidance of doubt, by anticompetitive effects we mean the foreclosure (and exit) of existing competitors who are as efficient as the dominant firm or the deterrence of potential competitors considering/contemplating market entry.

In modern EU competition law, both types of legal standards seem to jostle for a place in the assessment of abusive behaviour. The case law of the European Courts, and in particular of the ECJ, is in a state of limbo, sometimes appearing to require evidence of anticompetitive effects ${ }^{60}$ sometimes

that performance is measured precisely by total surplus, long-run productivity growth or some other objective quantity. This has greatly simplified both the policy debate and the technique of antitrust. To return to Baxter's maxim, whatever the rule or policy under scrutiny, in modern antitrust, 'if it doesn't make economic sense, it doesn't happen'. This has been a powerful clarifying aid to debate at all levels of antitrust".

59 See United Brands, supra n 40, paras 250-51.

60 See Case C-209/10 Post Danmark A/S v Konkurrencerådet, Judgment of 27 March 2012, not yet reported, paras 38 and 44: 
denying their relevance ${ }^{61}$ and, at other times, appearing to resort to an unsatisfactory hybrid of these two approaches.$^{62}$ In this context, courts and agencies across the EU appear entirely free to choose the legal standard they find appropriate when ruling on claims of exclusionary abuse, at least until the ECJ determines the issue. ${ }^{63}$ The European Commission's approach seems similarly schizophrenic. The effects-based approach appears to be supported by the Commission's Directorate General for Competition (DG COMP) and to manifest its desire to be held to a higher standard of proof in Article 102 cases, whilst the form-based approach appears to be supported by the Commission's Legal Service. In our opinion, given the significant potential for error of any form-based, structuralist analysis and the significant costs of those errors, the choice is clear.

Thirdly, a legal rule requiring mere proof of the likely effect of historic conduct is not a proper effects-based analysis unless a probability threshold is specified, and that threshold set at a sufficiently high level (eg the "in all likelihood" standard applied in criminal law). A legal standard that attaches antitrust liability to conduct that is merely "liable to" or "capable of" resulting in anticompetitive effects cannot be described as anything other than formalistic.

Fourthly, it is important to distinguish between the notion of foreclosure as shorthand for any restriction of rivals' access to supplies or customers due to conduct by the dominant firm (eg through the creation of a non-contestable

"to the extent that a dominant undertaking sets its prices at a level covering the great bulk of the costs attributable to the supply of the goods or services in question, it will, as a general rule, be possible for a competitor as efficient as that undertaking to compete with those prices without suffering losses that are unsustainable in the long term . . . In order to assess the existence of anti-competitive effects in circumstances such as those of that case, it is necessary to consider whether that pricing policy, without objective justification, produces an actual or likely exclusionary effect, to the detriment of competition and, thereby, of consumers' interests."

61 See Case T-219/99 British Airways plc v Commission [2003] ECR II-5917, para 293:

"for the purposes of establishing an infringement of Article [102 TFEU], it is not necessary to demonstrate that the abuse in question had a concrete effect on the markets concerned. It is sufficient in that respect to demonstrate that the abusive conduct of the undertaking in a dominant position tends to restrict competition, or, in other words, that the conduct is capable of having, or likely to have, such an effect".

See Case T-271/03 Deutsche Telekom v Commission [2008] ECR II-477, para 237; Case T-340/03 France Télécom SA v Commission [2007] ECR II-107, paras 195-96, confirmed in Case C-202/07 P France Télécom SA. v Commission [2009] ECR I-2369.

62 Case C-457/10 AstraZeneca v Commission, Judgment of 6 December 2012, not yet reported.

63 For examples of rulings suggesting that the Commission need not necessarily apply an effectsbased analysis see Case T-340/03 France Télécom SA v Commission [2007] ECR II-107, para 195; Case T-336/07 Telefónica and Telefónica de España v Commission, Judgment of 29 March 2012, not yet reported, para 268. This contrasts with the ruling issued in Post Danmark, supra n 60, para 44. 
share of the demand by means of exclusive purchase obligations ${ }^{64}$ ) from the proper notion of anticompetitive foreclosure, which requires proof that, as a (direct) result of the dominant firm's conduct, the existing as-efficient competitors and/or potential entrants are no longer able to act as an effective constraint on the dominant firm's pricing. ${ }^{65}$

Fifthly, establishing an abuse of dominance should require a high evidentiary burden. In principle, proof of an abuse can be based on evidence that the conduct in question produced either actual or likely foreclosure effects. As noted above, however, more weight should be given to the former than to the latter. Only where industry data are not available or are insufficient to show the actual existence or the absence of anticompetitive effects - as is often the case in nascent technology-enabled markets - will it be appropriate to attach antitrust liability to conduct by a dominant firm on the basis that it is likely to produce such effects. That said, as with any other legal rule that may encroach on fundamental rights and freedoms, ${ }^{66}$ as well as give rise to (quasi)criminal liability ${ }^{67}$ it is clear that the degree of likelihood required must be

64 See Tomra, supra n 57, para 41:

"However, in paragraph 240 of the judgment under appeal, the General Court properly approved the Commission's reasoning that, by foreclosing a significant part of the market, the Tomra group had restricted entry to one or a few competitors and thus limited the intensity of competition on the market as a whole."

65 It is obvious that such a standard deviates from some of the more recent rulings by the ECJ. For instance, in Tomra, which concerned several exclusivity agreements, quantity commitments and individualised retroactive rebate schemes entered into by a dominant firm, the Court dictated that "competitors should be able to compete on the merits for the entire market and not just for a part of it". See Tomra, supra n 57, para 42. Taken literally, this suggests that a dominant firm may be found guilty of an abuse as soon as it ties any share of market demand through exclusive arrangements, regardless of the magnitude of those arrangements (eg an exclusivity agreement that covers $1 \%$ of market demand, and that in turn leaves $99 \%$ of market demand open to rivals, could be held unlawful).

66 $\mathrm{Eg}$ the freedom to conduct a business (Article $16 \mathrm{EU}$ Charter), or the right to property, including intellectual property (Article 17 EU Charter).

67 See ECHR, 27 September 2011, A Menarini Diagnostics srl v Italy, request no 43509/08; Joined Cases C-201/09P and C-216/09P ArcelorMittal Luxembourg v Commission, Opinion of Advocate General Y Bot of 26 October 2010, [2011] ECR I-2239, paras 41 and 205: "While that procedure is not strictly speaking a criminal matter, it is none the less quasi-penal in nature". See also $\S 205$ :

"I am referring, in particular, to observance of the rights of the defence and of the principle of the presumption of innocence enshrined in Articles 47 and 48 of the Charter. The Court has repeatedly held that those fundamental rights, which are also safeguarded by Article 6 ECHR, must be observed in all proceedings relating to infringements of the competition rules capable of leading to penalties such as fines or periodic penalties, although the proceedings in question are administrative in nature. In that regard, the Court has expressly relied on the nature of the infringements in question and also on the nature and degree of severity of the ensuing penalties. I am also aware that respect for those guarantees is even more fundamental because the proceedings in question are quasi-penal in nature, where the Commission carries out the investigation, conducts the proceedings and adopts the decision, and in that regard has a wide discretion." 
high (as noted above, an "in all likelihood" standard). It follows that impressionistic theories based on speculative assertions that certain behaviour is merely "likely", "capable", "liable" or "tends" to produce past or future anticompetitive effects simply do not pass muster. ${ }^{68}$

Sixthly, a core component of any effects-based approach is the counterfactual, the purpose of which is to ascertain whether any observable effects on competition are caused by the dominant firm's conduct or are due to extraneous factors. In abuse of dominance cases, the applicable counterfactual comprises the market in the absence of the impugned practice. However, because technology-enabled markets are generally too new, such a counterfactual will often be unobservable, and it will be necessary to predict what the market would be like had the allegedly abusive conduct not taken place. This analysis is fraught with difficulties, given the scarcity of historical industry data and the absence of established business practices. ${ }^{69}$ These practical difficulties, however, should not be used as a pretext to do away with this important analytical step and blindly ascribe any observable foreclosure effects to the dominant firm's conduct. Rather, agencies should err on the side of caution, and reject allegations of abuse when no credible counterfactual can be identified, particularly as any intervention in technology-enabled markets risks stifling innovation. ${ }^{70}$

68 See Tomra, supra n 57, para 68:

"The General Court was correct to observe, in paragraph 289 of the judgment under appeal, that, for the purposes of proving an abuse of a dominant position within the meaning of Article 102 TFEU, it is sufficient to show that the abusive conduct of the undertaking in a dominant position tends to restrict competition or that the conduct is capable of having that effect."

69 See Communication from the Commission-Guidance on the Commission's enforcement priorities in applying Article 82 of the EC Treaty to abusive exclusionary conduct by dominant undertakings [2009] OJ C45/4 para 21:

"When pursuing a case the Commission will develop the analysis of the general factors mentioned in paragraph 20, together with the more specific factors described in the sections dealing with certain types of exclusionary conduct, and any other factors which it may consider to be appropriate. This assessment will usually be made by comparing the actual or likely future situation in the relevant market (with the dominant undertaking's conduct in place) with an appropriate counterfactual, such as the simple absence of the conduct in question or with another realistic alternative scenario, having regard to established business practices".

70 A possible methodology for dealing with such complex cases is to devise several counterfactual scenarios, assign to them distinct probability ratings (once an accurate scenario is available, its overall probability can be better assessed by assessing the probability of the various microsteps necessary for the scenario to occur) and finally assess allegedly abusive market conduct under each counterfactual, by order of descending probability. 


\section{F. Discussion of Various Types of Abuse in Teghnology-enabled Markets}

In our view, the widely acknowledged difficulty of distinguishing between abusive exclusionary conduct and aggressive, pro-competitive behaviour, which is common to all abuse of dominance cases, is magnified in technology-enabled markets. The most conventional theories of harm underpinning Article 102 claims can, on their face, easily apply to innovative and entirely pro-competitive conduct. For instance, the integration of added functionality to a software application - an entirely commonplace occurrence - can easily be portrayed as unlawful tying. In this section, we will briefly review different categories (or types) of abusive conduct and examine the pitfalls inherent in the application of the current loose legal standards to such conduct when it arises/occurs in technology-enabled markets.

\section{Excessive Pricing}

The prohibition against excessive pricing by dominant firms is the black sheep of EU competition law - and for good reason. The arguments against any attempt to control prices are not only well known in legal and economic theory but are also persuasive. Put simply, it is difficult to determine whether a price is excessive, and the risk of an erroneous determination is that it will chill competition and investment. ${ }^{71}$ As former DG COMP Chief Economist Lars-Hendrik Röller so aptly put it, "if there were no possibility to ever exploit one's market power, there would be no incentive to compete".$^{72}$ It is, therefore, unsurprising that the Commission has hitherto shown remarkable self-restraint and has only intervened to control the prices charged by dominant firms in very limited circumstances ${ }^{73}$ - predominantly

71 See generally OECD policy roundtable "Excessive Prices", DAF/COMP(2011) 18, available at http://www.oecd.org/dataoecd/5/3/49604207.pdf. See also D Evans and J Padilla, "Excessive Prices: Using Economics to Define Administrable Legal Rules" (2005) 1 fournal of Competition Law and Economics 97; A Ezrachi and D Gilo, "Are Excessive Prices Really Self-correcting" (2008) 5 Journal of Competition Law E Economics 249.

72 See LH Röller, "Exploitative Abuses", Business Brief No BB-107-002; ESMT European School of Management and Technology, 2007, 5.

73 "As regards exploitative practices, we are obviously aware that in many markets intervention by a competition authority will not be necessary. We are also aware that it is extremely difficult to measure what constitutes an excessive price. In practice, most of our enforcement focuses therefore as in the US on exclusionary abuses, ie. those which seek to harm consumers indirectly by changing the competitive structure or process of the market. It is not in our power to change the Treaty. And, in my view, we should continue to prosecute such practices where the abuse is not self-correcting, namely in cases where entry barriers are high or even insuperable. It probably makes also sense to apply those provisions in recently liberalised sectors where existing dominant positions are not the result of previous superior performance." See P Lowe, "How Different is EU Anti-trust? A Route Map for Advisors-An Overview of EU Competition Law and Policy on Commercial Practices", ABA Fall Meeting, 16 October 2003. 
as a means of preventing dominant firms from artificially fragmenting the internal market. $^{74}$

Price control in technology-enabled markets, which is characteristically innovation-intensive, should be viewed with even more caution. Despite the complexity of the relationship between innovation and market power (which we leave to economists far more capable than us to debate and explain ${ }^{75}$ ), in this we side with US Supreme Court Justice Scalia:

"The mere possession of monopoly power, and the concomitant charging of monopoly prices, is not only not unlawful; it is an important element of the freemarket system. The opportunity to charge monopoly prices - at least for a short period [emphasis added] — is what attracts "business acumen" in the first place; it induces risk taking that produces innovation and economic growth. To safeguard the incentive to innovate, the possession of monopoly power will not be found unlawful unless it is accompanied by an element of anticompetitive conduct." 76

That said, one of the arguments that is often raised to calm concerns that robust antitrust enforcement risks chilling innovation is that the IP laws already provide (or should provide) a sufficient reward to maintain those innovation incentives. ${ }^{77}$ But, if the IP laws fulfil that role, then antitrust agencies and courts should be especially wary of applying competition law to the exercise of IP rights, and in particular to the price under which IP is licensed.

It is, therefore, all the more surprising that the recent strand of cases in which the excessive pricing prohibition has been invoked concerns patents, and in the majority of cases patents that may be essential to a technical standard. Indeed, the terms under which high-tech companies license their standardessential patents (SEPs) appear to have become the most fertile of grounds for allegations and proceedings relating to excessive pricing.

Some of these cases concerned de facto standards (for instance, the Orange Book Standard cases recently ruled upon by the German Federal Supreme

74 See, eg Case C-26/75 General Motors v Commission [1975] ECR 1367, para 22; Case C-226/84 British Leyland Public Limited Company v Commission [1986] ECR 3263, para 29. As noted by Judge Nils Wahl,

"the prohibition against excessively high prices has its primary scope of application in situations of legal monopolies or regulated markets. In free markets it may principally be used when the pricing strategy focuses on something other than exploiting its customers on that particular product, for example by trying to prevent parallel imports".

See N Wahl, "Exploitative High prices and European Competition Law - a Personal Reflection" in A Fredenberg and N Strand (eds), The Pros and Cons of High Prices (Konkurrensverket, 2007), 64.

75 See R Gilbert, "Competition and Innovation" in W Collins (ed), Issues in Competition Law and Policy (American Bar Association Antitrust Section, 2006).

76 Emphasis added. See Verizon Comm'ns Inc v Law Offices of Curtis V Trinko, LLP, 540 US 398, 407 (2004).

77 See T Brennan, "Should Innovation Rationalize Supra-Competitive Prices? A Skeptical Speculation" in Fredenberg and Strand, supra n 74, 92. 
Court $^{78}$ and by the District Court of The Hague). ${ }^{79}$ The vast majority, however, concerned formal industry standards adopted by standard-setting organisations (SSOs) such as ETSI ${ }^{80}$ (for instance, the Qualcomm and IPCom investigations launched by the Commission). ${ }^{81}$

In some instances the antitrust liability claim was asserted by an alleged infringer in patent infringement proceedings before a national court (eg Apple's counterclaims in multiple patent infringements suits brought by Samsung in the EU). In others, it was raised in complaints brought before European competition authorities by implementers of the SEPs (for example, the investigations recently launched by the Commission against Samsung ${ }^{82}$ and Motorola ${ }^{83}$ regarding those companies' licensing practices). The argument raised by the implementer or prospective implementer of the standard in question differed depending on whether the patent owner had committed to license his patents on fair, reasonable and non-discriminatory (FRAND) terms or not. Where the patent owner had not given such a commitment, for instance because the standard was a de facto standard and not a formal standard adopted by a standard-setting body, the would-be implementer raised a so-called "competition law defence". In essence, the implementer claimed that Article 102 imposed on the patent owner a duty to license those patents essential to the standard on FRAND terms and that the royalties demanded by the patent owner were excessive and/or discriminatory and thus in breach of the requirement to license on FRAND terms. ${ }^{84}$ By contrast, where the patent owner had given a commitment to a standard-setting organisation that he would license his patents on FRAND terms, the implementer argued that the patent owner had breached that commitment because the royalties were excessive and/or discriminatory. In essence, the claim was that the alleged failure to comply

78 See Orange Book Standard, supra n 49.

79 See District Court The Hague, The Netherlands, 17 March 2010, Koninklijke Philips Electronics $\mathcal{N} V$ v SK Kassetten GmbH \& Co KG, Infringement, Joint Cases No 316533/HA ZA 08-2522 and 316535/HA ZA 08-2524.

80 The European Telecommunications Standards Institute "produces globally applicable standards for Information and Communications Technologies (ICT), including fixed, mobile, radio, converged, broadcast and internet technologies." See ETSI webpage, "About ETSI", available at http://www.etsi.org/website/aboutetsi/aboutetsi.aspx.

81 See Commission's Press Release, "Commission Welcomes IPCom's Public FRAND Declaration", MEMO/09/549, available at http://europa.eu/rapid/press-release_MEMO-09-549_en.htm; Commission's Press Release, "Commission Initiates Formal Proceedings against Qualcomm", MEMO/07/389, available at http://europa.eu/rapid/press-release_MEMO-07-389_en.htm.

82 See Commission's Press Release, "Commission Opens Proceedings against Samsung”, IP/12/89, available at http://europa.eu/rapid/press-release_IP-12-89_en.htm.

83 See Commission's Press Release, "Commission Opens Proceedings against Motorola", IP/12/345, available at http://europa.eu/rapid/press-release_IP-12-345_en.htm.

${ }^{84}$ For a critical appraisal of FRAND requirements see A Layne-Farrar, "Nondiscriminatory Pricing: Is Standard Setting Different?" (2010) 4 Fournal of Competition Law E Economics 811; M Mariniello, "Fair, Reasonable and Non-discriminatory (FRAND) Terms: A Challenge for Competition Authorities" (2011) 3 Journal of Competition Law E Economics 523. 
with the FRAND commitment represented a breach of Article 102 (this is sometimes referred to as "patent hold-up"). ${ }^{85}$

One of the remarkable aspects of all of those cases is the absence of a thorough legal analysis of the duties owed by owners of SEPs by Article 102. Although the Commission investigations were closed without a decision (Qualcomm) or are at too early a stage at the time this article is being written (Samsung, Motorola), press releases ${ }^{86}$ assorted statements ${ }^{87}$ and articles $^{88}$ by Commission officials seem to indicate that the Commission will examine allegations that royalties for SEPs are unreasonable under the excessive pricing legal standard set out by the ECJ in United Brands. The section on standardisation of the Commission's Horizontal Cooperation Guidelines appears to confirm this position, stating as it does that:

"In case of a dispute, the assessment of whether fees charged for access to IPR in the standard-setting context are unfair or unreasonable should be based on whether the fees bear a reasonable relationship to the economic value of the IPR." ${ }^{99}$

National courts seem to give even less regard to the analysis under Article 102. Although defendants in patent infringement proceedings brought by owners of SEPs routinely raise abuse of dominance defences under EU competition law or the equivalent domestic provisions applicable in the Member State(s), those courts have so far limited themselves to a few vague references to the duties imposed by those provisions which suggest, without explaining, that Article 102 may be relied upon to curb royalties (and other licensing terms) for SEPs. ${ }^{90}$

85 See HCG, supra n 47, §269. See also J Farrell, J Hayes, C Shapiro and T Sullivan, "Standard Setting, Patents, and Hold-Up" (2007) 74 Antitrust Law fournal 603; B Ganglmair, L Froeb and G Werden, "Patent Hold-Up and Antitrust: How a Well-Intentioned Rule Could Retard Innovation" (2012) 2 The Fournal of Industrial Economics 249; M Lemley and C Shapiro, "Patent Holdup and Royalty Stacking" (2007) 85 Texas Law Review, available at http://papers.ssrn.com/ sol3/papers.cfm?abstract_id=923468; E Elhauge, "Do Patent Holdup And Royalty Stacking Lead To Systematically Excessive Royalties?" (2008) 3 Journal of Competition Law Ë Economics 535.

86 See Commission's Press Release, "Commission Closes Formal Proceedings against Qualcomm", MEMO/09/516, available at http://europa.eu/rapid/press-release_MEMO-09-516_en.htm. See also the press releases concerning the Motorola and Samsung cases, supra n 82.

87 See Competition Commission's press release from December 2005 on their review of IPR rules at ETSI. See also J Almunia, "Keeping Markets Open and Efficient", SPEECH/12/172, presented at the European Competition and Consumer Day, Copenhagen, available at http:// europa.eu/rapid/press-release_SPEECH-12-172_en.htm.

88 See A Emanuelson, "Standardisation Agreements in the Context of the New Horizontal Guidelines" (2012) 2 European Competition Law Review 69, 76. See also C Madero and N Banasevic, "Standards and Market Power" (2008) 5 CPI Antitrust Chronicle 2.

89 See HCG, supra n 47, §289.

90 See eg Orange book Standard:

"The fact that the proposed licensee must have made an offer on acceptable contracting terms that the patent proprietor cannot refuse without discriminating the proposed licensee against similar companies without objective reason or without unduly obstructing him, is, to our knowledge, generally recognized, because the patent proprietor with a dominant position 
In our view, the straightforward application of the excessive pricing prohibition to the terms under which an owner of SEPs licences those patents is incorrect. This is not (simply) because the application of the United Brands test to the price of IPR is fraught with practical difficulties (which it undoubtedly is), but because it is inconsistent with the strand of well-established ECJ case law (Magill/IMS Health ${ }^{91}$ ), which provides that Article 102 will compel licensing of IPR (or, a fortiori, limit excessive pricing) only in "exceptional circumstances that prevent the development of the secondary market", and that a dominant firm does not abuse its dominant position merely by refusing to license IPR for a reasonable royalty unless three cumulative conditions are satisfied, namely that such a refusal: (i) prevents the emergence of a new product for which there is potential consumer demand; (ii) is unjustified; and (iii) is such as to exclude any competition on a secondary market (the IMS Health test). ${ }^{92}$

Our thesis is very simple: if a dominant firm can legitimately refuse to license its patents at any price, then it must surely follow that it can legitimately license them at any price it sees fit. Put another way, Article 102 can only be relied upon to limit the royalties available to a dominant owner of SEPs where Article 102 itself has given rise to an antitrust duty to license those patents. This duty cannot be contractual - in other words, it cannot stem from the FRAND commitment given to the SSO - rather, it has to be grounded in EU competition law itself. And the only legal authority that is capable of creating such a duty is the IMS Health case law on refusal to license.

on the market is not obliged to offer to permit the use of the invention; only if he declines an offer to conclude an agreement on non-restraining or discriminating terms, does he abuse his dominant position on the market. He does not have to tolerate the use of his patent by a company who is not ready to enter into a license agreement on such terms and conditions" (our translation).

91 See Case C-418/01 IMS Health GmbH \& Co OHG v NDC Health GmbH \& Co KG [2004] ECR I-5039, para 37 and ff.; see also Joined Cases C-241/91P and C-242/91P Radio Telefis Eireann (RTE) and Independent Television Publications Ltd (ITP) v Commission (Magill) [1995] ECR I-743, paras 49 and 50.

92 See IMS Health, supra n 91, para 52:

"Accordingly, the answer to the first question must be that the refusal by an undertaking which holds a dominant position and owns an intellectual property right in a brick structure indispensable to the presentation of regional sales data on pharmaceutical products in a Member State to grant a licence to use that structure to another undertaking which also wishes to provide such data in the same Member State, constitutes an abuse of a dominant position within the meaning of Article $82 \mathrm{EC}$ where the following conditions are fulfilled:

- the undertaking which requested the licence intends to offer, on the market for the supply of the data in question, new products or services not offered by the owner of the intellectual property right and for which there is a potential consumer demand;

- the refusal is not justified by objective considerations;

- the refusal is such as to reserve to the owner of the intellectual property right the market for the supply of data on sales of pharmaceutical products in the Member State concerned by eliminating all competition on that market." 
At least one Commission official has taken the position that the making of a FRAND commitment in a standard-setting context is in and of itself an exceptional circumstance under which Article 102 will compel licensing. ${ }^{93}$ This argument is not very persuasive. The making of a FRAND commitment and the licensing of SEPs cannot be considered exceptional circumstances in and of themselves. They are commonplace and well-understood business practices. Moreover, the economic and policy assumptions underlying the EGJ's cautious approach to compulsory licensing are just as relevant, if not more so, to the subject of excessive pricing of IPR. In our view, the fact remains that the IMS Health case law requires that the unilateral conduct by the patent holder excludes competition in a secondary market.

Some may be tempted to argue that the ruling by the ECJ in TeliaSonera ${ }^{94}$ would support the view that the excessive pricing prohibition can apply to licensing terms and conditions offered by an owner of SEPs who has given a FRAND commitment (assuming the patent owner is found to occupy a dominant position). The argument would be as follows. The Court held in TeliaSonera that a dominant firm's pricing practices could be found to be abusive (in casu, where it was claimed they led to a margin squeeze) in the absence of an antitrust duty to supply. To reach that conclusion, the Court first distinguished margin squeeze cases from cases of refusal to supply. ${ }^{95}$ It implied, at $\$ 25$ of its judgment, that a margin squeeze belongs to a distinct family of abuse, ie those that impose unfair prices on customers within the meaning of Article 102(a) TFEU. ${ }^{96}$ Subsequently, the Court went on to say, even more explicitly, that:

"It cannot be inferred from paragraphs 48 and 49 of [the Bronner] judgment that the conditions to be met in order to establish that a refusal to supply is abusive must

See Emanuelson, supra n 88, 75:

"The argument has sometimes been raised that competition law could not intervene against prohibitive pricing of IPR, or that at least competition law could not intervene absent the presence of "exceptional circumstances" such as those required for a refusal to license IPR to be abusive. Firstly, the case law of the European courts would not seem to require the presence of such exceptional circumstances absent the very specific situation of a refusal to license. Secondly, it is submitted that, should such "exceptional circumstances" be required, competition law intervention in the context of IPR could be justified by other circumstances than those relevant for a refusal to supply case. For example, in the Rambus case, the Commission's preliminary view was that without its "patent ambush," Rambus would not have been able to charge the royalty rates in question and that, in those very specific (or exceptional) circumstances, merely exercising its patent rights could be abusive. It could also be argued that the mere fact of having given a FRAND commitment (which implies a willingness to license) could also qualify as an "exceptional circumstance" (emphasis added).

94 See Case C-52/09 Konkurrensverket v TeliaSonera Sverige AB [2011] CR I-527.

95 Ibid, paras $56 \mathrm{ff}$.

96 Ibid, para 25:

"As regards the abusive nature of pricing practices such as those in the main proceedings, it must be noted that subparagraph (a) of the second paragraph of Article 102 TFEU expressly prohibits a dominant undertaking from directly or indirectly imposing unfair prices". 
necessarily also apply when assessing the abusive nature of conduct which consists in supplying services or selling goods on conditions which are disadvantageous or on which there might be no purchaser. Such conduct may, in itself, constitute an independent form of abuse distinct from that of refusal to supply." (emphasis added)

According to the Court, since margin squeeze and refusal to supply are two distinct forms of abuse, they can be examined under different legal standards. This would allow a finding of abuse in cases where the Bronner conditions are not satisfied, and in particular to ignore the requirement, in margin squeeze cases, that the input is indispensable for the customer to carry on its business.

In our view, TeliaSonera cannot be relied upon to apply the excessive pricing prohibition to the terms under which IPR is licensed (and, a fortiori, SEPs encumbered with a FRAND commitment) for the following reasons.

First, the IMS Health standard is lex specialis for refusals to supply where the object of the refusal relates to IPR ${ }^{97}$ As such, the reasoning in TeliaSonera, based, as it is, on a distinction between the lex generalis on refusal to supply goods or services and pricing practices relating to the supply of such goods or services, cannot be applied by analogy to a refusal to license IPR or the pricing of such IPR.

Secondly, and more importantly, TeliaSonera is an aberration: it lacks any semblance of internal logic, and is in addition indefensible from the standpoint of a cogent and modern application of EU competition law. If a firm can lawfully eliminate rivals by withholding the supply of a good, how can it be guilty of an abuse when it provides that good, albeit at a high price? ${ }^{98}$ Using

97 See Case C-7/97 Oscar Bronner GmbH \& Co KG v Mediaprint Zeitungs- und Zeitschriftenverlag GmbH \& Co [1998] ECR I-7791, para 41:

"Therefore, even if that case law on the exercise of an intellectual property right were applicable to the exercise of any property right whatever, it would still be necessary, for the Magill judgment to be effectively relied upon in order to plead the existence of an abuse within the meaning of Article 86 of the Treaty in a situation such as that which forms the subject-matter of the first question, not only that the refusal of the service comprised in home delivery be likely to eliminate all competition in the daily newspaper market on the part of the person requesting the service and that such refusal be incapable of being objectively justified, but also that the service in itself be indispensable to carrying on that person's business, inasmuch as there is no actual or potential substitute in existence for that homedelivery scheme" (emphasis added).

98 This seemingly straightforward observation also appears to have befuddled Advocate-General Mazák in the Opinion delivered in the TeliaSonera proceedings. After admitting that "if a dominant undertaking could lawfully have refused to provide the products in question, then it should not be reproached for providing those products at conditions which its competitors may consider not advantageous", AG Mazak then goes on to state the very opposite:

"It should certainly not be inferred from my analysis in all the foregoing paragraphs that the prices of a vertically integrated dominant undertaking cannot be abusive unless the input in question is indispensable or there is a regulatory obligation to supply that input. The upstream price may be excessive under Article 102(a) TFEU".

See Case C-52/09 Konkurrensverket v TeliaSonera Sverige AB, Opinion of Advocate General Mazák, 2 September 2010, [2011] ECR I-527, paras 21 and 32. 
a driving metaphor, this is akin to prohibiting speeding above $120 \mathrm{kph}$, yet tolerating it above $150 \mathrm{kph}$. The absurd consequence of the TeliaSonera ruling is that it may induce dominant firms to refuse to supply competitors outright rather than to share their inputs with them.

Thirdly, the Commission itself appears to have doubts as to the correctness of the TeliaSonera holdings. In the IBM commitment decision, the Commission examined allegations that IBM had imposed "unreasonable supply conditions with regard to certain inputs required for the maintenance of IBM mainframes on its competitors in the maintenance market, thus putting them at a competitive disadvantage"99 and took the initial view that IBM's conduct could amount to a constructive refusal to supply. ${ }^{100}$ However, after acknowledging the theoretical applicability of the TeliaSonera ruling to IBM's pricing practiceswhich would arguably have made a finding of abuse easier - the Commission proceeded to examine them under the Bronner standard, and considered in particular whether those inputs were indispensable for its rivals to compete. ${ }^{101}$

To conclude, we are of the view that a modern application of EU competition law grounded in logic and sound economic principles dictates that the prohibition of excessive or unfair pricing contained in Article 102(a) does not apply to intermediate goods, but only to final goods sold at the retail level to end-users. In the absence of an antitrust duty to deal, a dominant firm should be entirely free to set its prices at the level it sees fit. As the Latin aphorism goes, a majori ad minus.

Besides this, in a second strand of cases the Commission developed an even more creative interpretation of the excessive pricing prohibition. Those cases relate to so-called "patent ambush" strategies. ${ }^{102}$ In Rambus, the Commission

99 See IBM Maintenance Services [2012] OJ C18/6, para 4.

100 Ibid, para 32:

"The Commission preliminary concluded that the cumulative effect of the following features of IBM's behaviour with respect to the supply of essential inputs might amount to a constructive refusal to supply that could raison concerns under Article 102 of the Treaty."

101 Ibid, paras 37-38:

"The Court of Justice recently held that the conditions to be met under the Bronner line of case law do not necessarily apply when assessing the nature of conduct which consists in supplying services or selling goods on conditions which are disadvantageous or on which there might be no purchaser.

However, the Commission's preliminary view is that it would, in any case, be able to show that the inputs at issue here are indispensable in order to provide maintenance services for IBM mainframes. As explained in recitals (27) and (28), a number of inputs required to provide maintenance service to IBM mainframes (such as certain LICCC-enabled parts, Machine Code updates and operating system PTFs) cannot be sourced outside IBM and are subject to specific sourcing conditions. Since there can be no viable substitute for these essential inputs, the Commission took the preliminary view that these inputs may be indispensable to compete effectively with IBM on the relevant downstream market for maintenance for IBM mainframes."

102 The term "patent ambush" is usually employed to describe a situation where a patent owner wilfully and knowingly fails to meet its duty to disclose to an SSO ownership of patents which 
initially expressed concerns that Rambus Inc might have abused a dominant position by intentionally concealing from JEDEC SSO, in which Rambus participated, that it had patents and patent applications which were relevant to technology used in the DRAM standards ${ }^{103}$ being adopted by JEDEC, and subsequently claiming unreasonable royalties for those patents from suppliers of DRAM products. ${ }^{104}$ The Commission's view at the time was that, without its intentionally deceptive conduct, Rambus would not have been able to charge the royalties it subsequently did. The Commission indicated that under those circumstances Rambus's royalties were excessive and Rambus might be compelled to license the patents in question royalty-free.

From a theoretical standpoint, one of the most contentious aspects of the case was that it had been the allegedly deceptive conduct-Rambus's concealment of its patent position during the standard-setting efforts in which it had taken part - that had allowed Rambus to acquire a dominant position. In other words, the anticompetitive behaviour preceded and was the cause of the dominant position. However, it is a fundamental tenet of EU competition law that Article 102 does not censure the acquisition, or attempted acquisition, of dominance through anticompetitive means. ${ }^{105}$ Unlike Section II of the Sherman Act, which catches monopolising practices of non-dominant firms, Article 102 only applies to anticompetitive behaviour by firms that have already attained such a position of dominance.

In essence, in Rambus the Commission sought to apply the excessive pricing prohibition to close the "enforcement gap" described by former Chief Economist Röller. In short, Röller suggested that, in order to address the Commission's inability to sanction conduct that leads to a dominant position, the Commission should apply Article 102 to the outcome of that conduct, ie the prices charged by the dominant firm once it had acquired that dominant position - on the grounds that it had done so through anticompetitive exclusionary means. ${ }^{106}$

The Commission eventually closed its investigation by adopting an Article 9 decision that rendered legally binding the commitments offered by Rambus,

are subsequently incorporated in a standard under adoption. The fundamentally anticompetitive element in a patent ambush is the deception used by the holder of IPR to secure inclusion of its patents in the standard.

103 Dynamic Random Access Memory is a memory chip technology.

104 See Commission's Press Release, "Commission Confirms Sending a Statement of Objections to Rambus", MEMO/07/330, available at http://europa.eu/rapid/press-release_MEMO-07330_en.htm.

105 See Case C-322/81 NV Nederlandsche Banden Industrie Michelin v Commission [1983] 346, para 57.

106 "In other words, anticompetitive conduct that leads to a dominant position cannot be caught in Europe under Article 82 as an exclusionary abuse. This is enforcement 'gap', since it is precisely the way in which dominance is acquired that matters in terms of economic effects. I like to suggest that antitrust enforcement through exploitative abuse can be used to close this important gap. That is, exploitative abuse cases should be based on acquiring a dominant position through anti-competitive exclusionary conduct." See Röller, supra n 72. 
including a promise to cap the royalties that it would charge for certain patents essential for those DRAM products. ${ }^{107}$ It is, however, commonly accepted that the level at which Rambus agreed to cap its royalties was higher than that it could realistically have expected to obtain in the market - in other words, the commitment given by Rambus did not really constrain its commercial conduct. If it was the case that the Commission's apparent reluctance to adopt an infringement decision was due to a recognition (albeit implicit) of how ill-founded such an approach to the application of Article 102 would be, then it should be applauded. ${ }^{108}$ In our view, to use the excessive pricing prohibition to sanction behaviour that occurs ex ante the acquisition of a dominant position is not only a contra legem application of Article 102, but is also fraught with practical difficulties, including the need to create entirely new legal standards to determine the types of conduct that should be deemed anticompetitive.

\section{Refusal to Supply}

Most allegations of abusive refusal to supply in technology-enabled markets concern interoperability issues in the ICT sector. In this section, we thus explore the concept of interoperability (a), review the existing case law (b) and shed light on a number of misconceptions related to this issue (c).

107 See Commission's Press Release, "Antitrust: Commission Accepts Commitments from Rambus Lowering Memory Chip Royalty Rates", IP/09/1897, available at http://europa.eu/rapid/ press-release_IP-09-1897_en.htm. Of course, the Commission considered, in its decision, that Rambus had occupied a dominant position since the initiation of the impugned conduct. However, if this is the case, what was Rambus's interest in allegedly resorting to deceptive tactics to hide its SEPs? Moreover, the Commission also noted that there were alternatives prior to standardisation $(\$ 46)$, and that standard participants might have innovated around Rambus's technology. If this is true, this means that Rambus did not enjoy a dominant position when it resorted to abusive conduct.

108 A Dutch court recently reached a similar conclusion regarding claims by Apple that Samsung had abused a dominant position by only disclosing its ownership of certain patents to ETSI after standard adoption. ("To the extent that Apple meant to argue that Samsung, as a result of the late notification, abused a dominant position within the meaning of Article 24 of the Dutch Competitive Trading Act or Article 102 of the TFEU this line of reasoning must be dismissed. It has neither been argued nor become apparent that Samsung already had a dominant position within the meaning of those provisions at the time of the development of the $3 \mathrm{G}$ Standard. Apple only argued that Samsung obtained a dominant position by lending its cooperation to the establishment of that standard whilst referring to its patent applications. Whatever may be of this, Samsung rightly and undisputedly argued that the creation of a dominant position has not been prohibited by article 24 of the Dutch Competitive Trading Act or article 102 of the TFEU" our translation). See District Court The Hague, The Netherlands, 14 March 2012, Samsung Electronics Co Ltd v Apple Inc et al, Case numbers 400367/HA ZA 11-2212, 400376/HA ZA 11-2213 and 400385/HA ZA 11-2215. 




Fig 2 The IT Stack

Source: Commission Decision in Oracle/Sun Microsystems

\section{(a) The Notion of Interoperability}

In the field of computer technologies, the notion of interoperability has two variants. ${ }^{109}$ In the first variant, there is vertical interoperability when the various layers of IT infrastructure - also called the IT stack, ie hardware, OS, databases, middleware and application software - are able "to exchange information and mutually use the information which has been exchanged" (see Fig 2). ${ }^{10}$ Vertical interoperability thus refers, for instance, to interoperability

109 Interoperability bears resemblance with familiar concepts of the real economy, such as "interconnection" in recently liberalised industries (eg in the energy, railway, postal sectors), or technical compatibility standards adopted within standard-setting organisations.

110 See Council Directive 91/250/EEC of 14 May 1991 on the legal protection of computer programs [1991] OJ L122/42, para 10. For more on this see A Van Rooijen, The Software Interface between Copyright and Competition Law (Kluwer Law International, 2010), 8. 
between the complementary components of computer systems (eg a Samsung Smartphone and a Google OS). ${ }^{11}$

A second variant of the notion is horizontal interoperability. This refers to the ability of information to be communicated across distinct technological platforms which perform a similar function. In other words, horizontal interoperability is interoperability between substitute technology platforms (eg Windows OS and Linux OS). ${ }^{112}$

Often, interoperability is deemed procompetitive. ${ }^{113}$ Vertical interoperability ensures that users who have chosen a particular functional component (eg a specific OS) remain free to select complementary components from several competing suppliers (eg of word processing applications), and are not locked-in within a particular technological silo (eg all components must be sourced from the same supplier). By the same token, horizontal interoperability keeps technology-enabled markets open to competition. If, as is often the case as a result of network effects, a particular technological standard tips the market (eg Windows OS), interoperability ensures that new technological platforms (eg Linux OS) can exert potential competition on the established de facto standard, as users selecting the new technology will be able to communicate with users of the incumbent technology. ${ }^{114}$

\section{(b) The Case Law on Interoperability}

For the reasons discussed above, conduct by dominant firms that limits, degrades or even prevents interoperability is usually viewed with suspicion by courts and agencies, and often gives rise to the initiation of proceedings. ${ }^{115}$ Several cases illustrate this and shed light on the conditions under which interoperability degradation tactics will be considered abusive.

111 For instance, there is vertical interoperability when a user willing to listen to digital music selects a title within his OS musical library. The OS will in turn send the data to a media player. And the media player will instruct the computer's hardware (ie the speakers) to display the sound.

112 Horizontal interoperability takes place, for instance, if a user shares - eg by e-mail or by USB transfer - a digital file with a relative who uses a different type of media player (eg RealPlayer or Windows Media Player). On this see B Rotenberg, "The Legal Regulation of Software Interoperability in the EU', Jean Monnet Working Paper 07/05, footnote 25. Although encoded in a distinct language, the digital file may be played on the relative's media player.

113 See C Madero Villarejo, speech given at Annual Conference on European Antitrust Law, Brussels, 3 March 2011, available at http://ec.europa.eu/competition/speeches/text/ sp2011_02_en.pdf, stressing "that these (interoperability solutions) favour market entry by a greater number of players . . . they stimulate competition in high-tech industries."

114 See Van Rooijen, supra n 110, 24.

115 Vertically integrated or conglomerate technology suppliers who sell complements may want to benefit from so-called lock-ins. Van Rooijen notes that technology suppliers may try to prevent interoperability with other programs to exclude competition, and obtain a de facto exclusivity over a market (ibid, 10). 


\section{(i) IBM 1984 Undertaking ${ }^{116}$}

The first allegations of abusive interoperability tactics lodged before the Commission date back to 1980, when a number of complainants alleged that IBM had failed to supply other manufacturers with the technical information needed to permit competitive products to be sold with IBM's System/370 family of mainframe computers. The Commission opened an investigation and, following protracted negotiations with IBM, reached a settlement. IBM committed to supply interface information between or to all layers of the IT stack, including: (i) System 370 hardware products; (ii) System 370 CPU and software products; and (iii) System 370 software products. ${ }^{117}$ Between 1 August 1984 and July 1995, IBM received a total of 262 interoperability requests from 24 competitors and containing 2001 individual questions. ${ }^{118}$

\section{(ii) Microsoft I (2004)}

The EU Microsoft I case of 2004 is perhaps the best example of a vertical interoperability abuse. In this case, Sun Microsystems, a software producer, claimed that Microsoft had degraded the interoperability of Sun's group server OS with the dominant Windows OS for PCs, in order to advantage its Windows group server OS. As a result, Sun had been unable to attract clients to its group server OS, as it did not communicate well with the widespread Windows OS for PCs.

The Commission found that Microsoft had abusively withheld essential interoperability information from Sun Microsystems. ${ }^{119}$ It held that:

"Due to the lack of interoperability that competing work group server operating system products can achieve with the Windows domain architecture, an increasing number of consumers are locked into a homogeneous Windows solution at the level of the work group server operating system. This impairs the ability of such customers to benefit from innovative work group server operating system features brought to the market by Microsoft's competitors. In addition, this limits the prospect for such competitors to successfully market their innovation and thereby discourages them from developing new products." ${ }^{120}$

116 See IBM Personal Computer [1984] OJ L1 18/24.

117 Under the settlement, IBM reserved the right to make a reasonable and non-discriminatory charge to cover the cost of reproduction and dissemination of interface information supplied pursuant to the undertaking it made to the Commission, as well as the right to charge a reasonable and non-discriminatory royalty for the supply of proprietary information protected by any right enforceable at law.

118 See F Lomholt, "The 1984 IBM Undertaking Commission's Monitoring and Practical Effects" [1998] Competition Policy Neresletter 3, 10, available at http://ec.europa.eu/competition/publications/cpn/cpn19983.pdf.

119 See Microsoft, supra n 23, paras 560-84.

120 Ibid, para 694 . 
The Commission imposed a €497,000,000 fine and ordered Microsoft to provide rivals with detailed technical specifications enabling them to implement Microsoft's protocol technology in their own competing server products. ${ }^{121}$ The Commission's decision was subsequently challenged before the General Court $(\mathrm{GG})$. Amongst the dozens of interesting legal questions raised by the case, the GC had to determine whether the traditional ECJ case law on abusive refusal to deal was applicable to refusals to supply interoperability information, possibly protected by IPRs. Under the Magill/IMS Health standard set out by the ECJ, the refusal by a dominant firm to grant IPR licences can only be considered an abuse in exceptional circumstances. ${ }^{122}$ As noted previously, a dominant firm does not abuse its dominant position merely by refusing to license IPR unless such refusal: (i) concerns a product that is indispensable for the production of a "new product for which there was clear and unsatisfied consumer demand"; (ii) results in the elimination of all of the competition on the market; and (iii) has no objective justification.

In the Microsoft judgment, the GG appears to have departed from that case law. It held that:

"the circumstance relating to the appearance of a new product, as envisaged in Magill and IMS Health . . . cannot be the only parameter which determines whether a refusal to license an intellectual property right is capable of causing prejudice to consumers within the meaning of [Article 102(b) TFEU]". ${ }^{23}$

The GC added that it was sufficient for the Commission to prove that the refusal to supply interoperability information gives rise to a "limitation . . . of technical development". ${ }^{124}$

The GC's judgment has sparked intense controversy amongst EU competition scholars for two reasons. ${ }^{125}$ First, it considerably lowers the threshold at which the exercise of IPRs can be deemed abusive by replacing the condition that the refusal to supply must prevent the appearance of a new product with

121 Microsoft was also required to provide its competitors with licences to Microsoft's IPRs in the protocols, including patents, copyrights and trade secrets covering software and the specifications.

122 See Radio Telefis Eireann, supra n 91; IMS Health, supra n 91.

123 See Case T-201/04 Microsoft Corp v Commission [2007] ECR II-3601, para 647.

124 Ibid.

125 The Microsoft ruling is criticised, often by comparison with the prior Magil/IMS case law. See, eg J Kilick, "IMS and Microsoft Judged in the Cold Light of IMS" (2004) 1 The Competition Law Review 23; A Devlin and M Jacobs, "Microsoft's Five Fatal Flaws" (2009) 67 Columbia Business Law Review, available at http://papers.ssrn.com/sol3/papers.cfm?abstract_id=1429574; S Subramanian, "The Microsoft Decision: A Setback to IP Rights in Europe?" (2010) 4 Fournal of Intellectual Property Law \& Practice 245; L Hou, "The Essential Facilities Doctrine-What Was Wrong in Microsoft?" (2012) 43(4) IIC-International Review of Intellectual Property and Competition Law 251 (available at: http://papers.ssrn.com/sol3/papers.cfm?abstract_id=2025777. 
mere proof that it impairs "technical development". ${ }^{126}$ Secondly, the notion of conduct that limits "technical development" is inherently loose and openended, and as such prone to diverging interpretation.

It is, however, questionable whether the Microsoft I ruling it still good law. In yet another Microsoft I ruling of June 2012 - this time related to the fine imposed on Microsoft for non-compliance with the Commission's decisionthe GC apparently overruled its 2007 judgment and reinstated the Magill/ IMS Health standard. This judgment, which says no word of a "limitation of technical development", contains an obiter dictum where the GC explicitly refers to the "new product" condition, and quotes IMS Health as the sole source of precedent on refusals to supply involving IPRs.

"In that regard, it should be recalled that, in order for the refusal by an undertaking which owns a copyright to give access to a product or service indispensable for carrying on a particular business to be regarded as abuse, it is sufficient that three cumulative conditions be satisfied, namely that that refusal is preventing the emergence of a new product for which there is a potential consumer demand, that it is unjustified and that it is such as to exclude any competition on a secondary market." 127

Given the EU judicature's well-known aversion for explicit case law reversals, it comes as no surprise that the GC here did not clearly recognise that it applied a wrong legal standard in 2007. ${ }^{128}$ That said, paragraph 139 marks a clear and welcome evolution of the case law on abuse, because it eradicates the loose, unpractical and unsound legal standard heralded in the first Microsoft I judgment.

(iii) Apple/Virgin Mega

Several national cases also shed light on the conditions necessary to establish a vertical interoperability abuse. In the Apple/Virgin Mega case, ${ }^{129}$ Virgin Mega, a French online music provider, alleged that Apple was using its digital rights management (DRM) technology — a system which protects digital music files from piracy - to abusively foreclose competition, and requested interim relief. ${ }^{130}$ Apple's music players (ie iPods) could only read music protected by Apple's own FairPlay DRM technology. Apple kept exclusive control of the FairPlay DRM

${ }^{126}$ For an interpretation of this trend according to the value of the IPR at stake see A Van Rooijen, "The Role of Investments in Refusals to Deal" (2008) 1 World Competition 63.

127 See Case T-167/08 Microsoft Corp v Commission, Judgment of 27 June 2012, not yet reported, para 139.

128 It thus goes on to state in the following paragraph that those three conditions were met in the Microsoft I case (quod non).

129 See French Council for Competition, 9 November 2004, Apple Computer v VirginMega, Decision no 04-D-54.

130 A DRM is a system of technical measures which restricts the possible use of a song/title, once downloaded by a music customer. 
for music sold in its online store iTunes as it did not license the FairPlay DRM to other online music vendors (such as Virgin Mega). The plaintiff argued that competing online music stores were harmed because they were prevented from selling digital music to iPod users.

The French competition authority rejected all of the allegations. Remarkably, it began by stressing that a number of market characteristics militated against a finding of dominance: dynamic and growing market, entry of new competitors, downwards pressure on prices, significant investments, increase in product functionalities, etc. Secondly, the French authority ignored the GC's Microsoft ruling and applied instead the Magill/IMS Health legal standard. On the condition of "indispensability", it found that FairPlay was not indispensable to operate on the online music market. Online music was not only listened to on digital music players. Most consumers listened to music on their PCs, and thus Virgin Mega could sell to music consumers other than iPod users. Moreover, iPod users could download music from Virgin Mega and then transfer it to their iPods by burning a CD. Finally, many digital music players were appearing in France at the time. The size of the market addressable by Virgin was therefore expanding.

Regarding the second condition of the Magill/IMS Health test, the French competition authority interpreted the expression "elimination of competition" as meaning "a complete elimination" of competition. It noted that, in the case at hand, there was no risk of a complete elimination of competition. The market for online music downloads was considered buoyant, with six operators, two new entrants and numerous potential competitors.

Finally, it is noteworthy that the French competition authority added a fourth condition to the analysis and therefore applied a stricter standard than Magill/IMS Health. This is because it examined whether there was a causal link between the alleged abusive behaviour and the conditions of competition observed in the market. In other words, the French competition authority applied the sort of effects-based approach that we support. In the extant case, the agency found no evidence of a causal link between Apple's alleged abuse and Virgin Mega's lack of commercial success, which could be explained by a range of other factors: a limited musical catalogue $(350,000$ v 700,000 tracks for Apple), inefficient pricing policy (€1.19 per track $\mathrm{v} € 0.99$ per track for Apple) and limited marketing expenditure.

(iv) Merger Cases

The issue of interoperability has also triggered foreclosure concerns in the distinct, yet close, area of EU merger control. ${ }^{131}$ A first string of cases concerns

131 For a good review of merger cases, see T Hoehn and A Lewis, "Interoperability Remedies and Innovation: A Review of Recent Case Law", mimeo, Competition Rx, 2012, available at http://www3.imperial.ac.uk/intellectual-property-research/research. 
vertical interoperability in the ICT sector. In Oracle/Sun Microsystems, ${ }^{132}$ the Commission initially feared that the merged entity would degrade interoperability between the widely distributed database MySQL and competing storage engines providers. ${ }^{133}$ During the course of the investigation, these concerns were allayed on the grounds that MySQL was licensed under the most widely used open source licence, the General Public License v2 (GPL), ${ }^{134}$ and that Oracle had publicly announced that it would continue to enhance MySQL and make subsequent versions of MySQL available under the GPL. ${ }^{135}$

The Intel/McAfee case appears to have given rise to more serious concerns of potential degradation of vertical interoperability. ${ }^{136}$ In this case, the Commission was called upon to review the acquisition by Intel, the world-leading manufacturer of computer chips and chipsets, of McAfee, a vendor of information technology security (eg antivirus software). The Commission found that, postmerger, the merged entity would have the ability and incentives to degrade the interoperability of: (i) rival firms' security solutions with Intel CPUs and chipsets; ${ }^{137}$ and (ii) rival non-Intel CPUs and chipsets with McAfee security solutions, leading to an Intel/McAfee "security monoculture". To dispel the Commission's concerns, Intel undertook, among other things, to ensure, on an ongoing basis and in a timely manner, that instructions and interoperability information for new functionalities in Intel CPUs and chipsets would be documented and available for use by independent security software vendors on

132 See Case COMP/M.5529 Oracle/ Sun Microsystems, available on DG Competition's website.

133 See CC Buhr, S Crome, A Lübbert, V Pozzato, Y Simon and R Thomas, "Oracle/Sun Microsystems: The Challenge of Reviewing a Merger Involving Open Source Software" (2010) 2 Competition Policy Newsletter 25, available at http://ec.europa.eu/competition/publications/ cpn/2010_2_5.pdf:

"Oracle might have stopped offering or developing or might degrade MySQL under the GPL, or that Oracle might remove the constraint exerted by third-party storage engines by modifying the interface or refusing to grant storage engine vendors the commercial licenses that would allow them to market proprietary versions of their storage engines to work with MySQL".

134 GPL is the most widely used open source licence. One of the characteristics of the GPL is that, if a product, which contains modified or unmodified MySQL source code and thus is a "derived work" in the sense of copyright law, is commercialised, then it must also be licensed under the GPL and its entire source code must be disclosed to the public. This is sometimes described as the "viral" effect of the GPL.

135 Furthermore, Oracle pledged to maintain and periodically enhance MySQL's pluggable storage engine architecture to allow users the flexibility to choose from a portfolio of storage engines, including those developed by third parties. Also, Oracle pledged not to demand that third-party storage engine vendors obtain commercial (non-GPL) licences in order to implement the application programming interfaces available as part of MySQL's architecture.

136 See Case COMP/M.5984 Intel/McAfee, available on DG Competition's website.

137 As noted by Commission officials, interoperability degradation "can take several forms, such as non-availability of certain hardware instructions or functions, delayed or incomplete disclosure of support tools and of information on hardware instruction sets and architecture". See J Guitton, A Lübbert, I Neale-Besson and J Vidal, "Intel/McAfee" (2011) 2 Competition Policy Newesletter 10, available at http://ec.europa.eu/competition/publications/cpn/2011_2_3_en.pdf. 
a royalty-free basis. ${ }^{138}$ In addition, Intel committed not to actively impede competitors' security solutions from running on Intel's CPUs or chipsets. ${ }^{139}$

Finally, the Commission's decision in Cisco/Tandberg provides an example of horizontal interoperability concerns. ${ }^{140}$ The Commission was called upon to review a merger between two suppliers of video communications solutions (VCS). The Commission's investigation focused in particular on the market segment for dedicated room systems (eg three-screen VCS). Because firms generally source VCS from only one supplier, a certain degree of horizontal interoperability is necessary when several firms willing to videoconference have different VCS suppliers and equipment. In the Commission's view, the proposed merger could have undermined horizontal interoperability between VCS. A key aspect of the Commission's concern was the fact that Cisco controlled the key TIP protocol for communications between Cisco's three-screen VCS and competitors' three-screen VCS. The Commission thus feared that Cisco's incentives to interoperate might change post-merger. The Commission noted that, whilst Cisco would probably keep an incentive to interoperate with its main competitors, it would have increased incentives to strategically degrade interoperability with new entrants or less important competitors. ${ }^{141}$ To address the Commission's concerns, Cisco committed, inter alia, to divest the rights attached to its proprietary protocol TIP to an independent industry body. ${ }^{142}$

138 Ibid, 11.

139 Interestingly, issues of vertical interoperability also arose in sectors alien to ICT, such as medical systems sold to hospitals. In Siemens/Drägerwerk [2003] OJ L291/1 the parties transferred to a joint venture their respective activities in patient monitors on the one hand, and in ventilators and other medical equipment on the other hand. With this joint venture, the Commission feared the creation of a technological silo. In particular, the joint venture could have sought to give preference to Siemens's patient monitors by withholding the interface information necessary for competitors' monitors to be able to interface with the ventilators and other relevant equipment sold by the joint venture. This would have led to a reduction in the choice of patient monitors for hospitals, as well as price increases. To dispel the Commission's concerns, the parties agreed to provide the necessary electrical and mechanical interface for rivals' patient monitors to be able to interoperate with its own equipment used in operating theatres and intensive care units. A similar issue arose in GE/Instrumentarium [2004] OJ L109/1. The Commission feared that, post-merger, GE could favour its own critical care and perioperative patient monitors, as well as its clinical information system, by withholding the interface information necessary for competitors' own systems to interoperate with the anaesthesia delivery systems and other relevant equipment sold by the merged entity. Remedies analogous to those accepted in Siemens / Drägerwerk were imposed to allay the vertical interoperability concerns.

140 See Case COMP/M.5669 Cisco/Tandberg, available on DG Competition's website.

141 Ibid, $\$ 81$.

142 It also committed to ensure interoperability with Cisco's solutions and to allow other vendors to participate in the development and in the updates of such protocol. 


\section{(v) Pending and Upcoming Cases}

In recent years, there has been a resurgence of cases involving claims of abusive interoperability tactics. ${ }^{143}$ The ongoing mega-investigation against Google is a good example of this. One of the main allegations in that case is that Google has downgraded rivals' interoperability with its services through a range of abusive tactics. ${ }^{144}$ First, since the acquisition of the website www.youtube.com (which hosts video clips), Google would have adopted technical measures to restrict competing search engines from properly indexing youtube.com links on search results pages. Secondly, Google would have refused to allow mobile telephones running Microsoft's new Windows Phone OS to access YouTube metadata in the same way as Android telephones and iPhones do. ${ }^{145}$ Thirdly, Google would have contractually prohibited advertisers from using their data in an interoperable way with other search advertising platforms (such as Microsoft's adCenter). ${ }^{146}$

More recently, the Commission opened a formal investigation against MathWorks following allegations of abusive interoperability tactics. ${ }^{147}$ MathWorks designs and sells mathematical computing software. Two of its software products, Simulink and MATLAB, are used by engineers in the car industry to design control mechanisms for automotive vehicles (eg cruise control systems, anti-lock braking systems (ABS) and parking controls). The Commission is examining whether MathWorks rejected a rival software firm's request for end-user licences and interoperability information. The Commission seems concerned that MathWorks sought to prevent that rival from reverse engineering MathWorks products and, in turn, designing competing software useful to the automotive industry. It should be noted that the purpose of reverse

143 This is all the more surprising, given that the Commission seems itself a little lost in the jungle as regards interoperability (it does not know what to favour or the extent of the problem). See "Public Consultation on the Access to Interoperability Information of Digital Products and Services", available at http://ec.europa.eu/yourvoice/ipm/forms/dispatch?form=Interoperabi lity\&lang=EN.

144 See the Microsoft blog post talking of a "broadening pattern of walling off access to . . . data that competitors need": B Smith, "Adding our Voice to Concerns about Search in Europe", Microsoft on the Issues, 30 March 2011, available at http://blogs.technet.com/b/microsoft_on_ the_issues/archive/2011/03/30/adding-our-voice-to-concerns-about-search-in-europe.aspx.

145 Google has enabled its own Android phones to access YouTube so that users can search for video categories, find favourites, see ratings, and so forth in the rich user interfaces offered by those phones. It has done the same thing for the iPhones offered by Apple, which does not offer a competing search service. But Microsoft's YouTube "app" on Windows Phones is basically just a browser displaying YouTube's mobile website, without the rich functionality offered on competing phones.

146 In a recent speech, the Commissioner for Competition, however, suggested that only this latest interoperability allegation could give rise to serious doubts of abuse. See "Statement of VicePresident Almunia on the Google Antitrust Investigation", supra n 25.

147 See Commission's Press Release, "Commission Opens Proceedings against MathWorks", IP/12/208 (1 March 2012), available at http://europa.eu/rapid/press-release_IP-12-208_ en.htm. 
engineering is to reproduce another firm's software and is wholly lawful. ${ }^{148} \mathrm{It}$ can be achieved through one of two different methods. One method consists in observing what the software does in order to reconstruct how it does it (so-called "black box testing"). The other method consists in decompiling the observable software object code (an obscure list of binary $1 \mathrm{~s}$ and $0 \mathrm{~s}$ ) into source code (a humanly readable set of instructions). In this second variant, reverse engineering can only take place if the software's object code is available (so-called "white box testing"). ${ }^{149}$ But this is not sufficient, and decompiling will often be complex and costly. The Commission's concern seems to focus on the risk that MathWorks has prevented rivals from analysing Simulink and MATLAB's object code. ${ }^{150}$

Interoperability issues are also at the heart of an ongoing complaint lodged by Versata, a US software producer, against SAP, the leading supplier of business management software. ${ }^{151}$ Versata alleges that SAP has manipulated interfaces in order to undermine the interoperability of SAP's Enterprise Resource Planning applications with Versata's Pricer software.

Finally, interoperability is a bone of contention in the annulment proceedings introduced by Cisco Systems against the Commission's decision approving the Microsoft/Skype merger. ${ }^{152}$ In its application, Cisco argues that, with access to the large mass of Skype users (several hundred million), Microsoft will seek to create a preferential interoperability link with its Lync applications for unified communications services (eg instant messaging, telephony, videoconferencing). ${ }^{153}$ According to Cisco, customers of unified communications services will logically choose Lync over rival unified communications services simply because it will be the sole software interoperable with Skype's large installed base.

\section{(c) Misconceptions on Interoperability}

The increase in the number of recent interoperability abuse cases makes it important to dispel a number of misconceptions regarding interoperability.

148 See Van Rooijen, supra n 110, 18.

149 Source code, in contrast, is often protected by copyrights, and thus not freely accessible.

150 See Commission's Press Release, "Commission Opens Proceedings against MathWorks", supra n 147.

151 See M Tricker and M Waha, "Antitrust and Technology in Europe and Asia: Microsoft on the Attack - Google under Investigation", available at http://www.nortonrose.com/knowledge/ publications/33109/antitrust-and-technology-in-europe-and-asia-microsoft-on-the-attack-googleunder-investigation; F Mueller, "Versata Complains against SAP: Patent Aggressor Demands Interoperability, Requests Antitrust Intervention", Foss Patent, 30 June 2010, available at http:// www.fosspatents.com/2010/06/versata-complains-against-sap-patent.html.

152 See Case COMP/M.6281 Microsoft/ Skype, available on DG Competition's website. See also the appeal brought against this decision. Case T-79/12 Cisco Systems and Messagenet v Commission [2012] OC C109/31, action brought on 15 February 2012.

153 Microsoft will in contrast allegedly degrade interoperability with rival software for unified communications. 
First, the contribution of interoperability to welfare remains wholly unclear. Whilst, at first blush, interoperability seems to foster competition, the reality is much more complex.

\section{(i) Misconception No 1}

On the one hand, there may be an erroneous presumption that markets where products are not interoperable are insufficiently competitive. Although in such markets consumers may tend to choose the product with the highest number of users (due to positive externalities), and the market may subsequently "tip" towards that product, this does not mean that such markets are not competitive. In such cases, competition takes place ex ante, for the tipped monopolistic market position. Also, whilst ex post competition may be reduced, some markets often take a long time to tip in favour of one allegedly dominant firm (and some never do). Moreover, in markets with non-interoperable technologies, vigorous ex post competition may - and will - often arise out of disruptive technologies or drastic innovations, with new players innovating around the monopoly, and displace the process of competition towards other products. This is the well-known process of dynamic creative destruction introduced by Schumpeter. ${ }^{154}$

Conversely, markets where products are interoperable are all too often deemed competitive. In such markets, however, firms' ex ante incentives to compete on drastic innovations may be reduced by the necessity to ensure interoperability. Firms will thus rather compete in the market within a similar technological ecosystem. The process of competition in turn will take place $e x$ post, through the introduction of incremental innovations, whose contribution to welfare will be much less than that of disruptive innovations.

All in all, neither of those two models of competition can be said to be better than the other. From a competition policy standpoint, this implies that courts and agencies should not blindly favour interoperability in all cases (some agencies seem to be real interoperability addicts) as that would mean an unfounded bias in favour of incremental innovation and against drastic innovation.

\section{(ii) Misconception No 2}

Technological interoperability is polymorphous. The fact that a company will limit the interoperability of the technology it supplies does not necessarily mean that those products will not be able to interoperate at all with products supplied by rivals. The supplier of an OS (eg Microsoft and its Windows OS) may choose not to make its OS vertically interoperable with complementary application software products designed by competitors (eg Apple word-processing

154 See J Schumpter, Capitalism, Socialism, and Democracy (Harper, 1975). 
applications cannot be installed on Windows), yet ensure horizontal interoperability with a substitutable rival OS (eg Windows for PC and Apple iOS communicate, allowing users of both OS to exchange data, emails, documents, etc) and vice versa.

(iii) Misconception No 3

Reverse engineering can transform non-interoperable, closed technological platforms into open ones. For instance, it has often been reported that Real Networks reverse engineered Windows Media Player or Apple's DRM, thereby fostering competition in online music and triggering market entry. ${ }^{155}$ The procompetitive effects of reverse engineering, and in particular of black box testing, are often underestimated. As a matter of best legal practice, courts and agencies should scrutinise the scope for reverse engineering prior to investigating any allegation of abusive interoperability tactics.

(iv) Misconception No 4

Attempts to ensure interoperability on the basis of the antitrust laws usually produce complex remedies which require courts and agencies to play roles best left to engineers and/or marketing managers. The Microsoft case illustrates this point. Once the Commission had found an infringement, a remedy ensuring adequate interoperability conditions with rival OS for servers rivals had to be crafted. To make its life as easy as possible, the Commission took the view that it was not its role to tell Microsoft how to comply with its decision and eliminate the abuse. It thus delegated to Microsoft the duty to devise an appropriate technical and commercial remedy. This, in turn, triggered an endless discussion between Microsoft and the Commission on the appropriate technical (adequate level of technical documentation) and commercial conditions (eg licensing fees) for the disclosure of Windows' specifications. ${ }^{156}$ It ultimately took Microsoft over three years to propose and implement a remedy deemed suitable by the Commission. On top of this, a specific monitoring mechanism (eg appointment of a trustee, reporting duties, penalty payments) had to be set up to ensure that Microsoft would comply over time with the remedial order. ${ }^{157}$ For these reasons, we consider that the courts are ill-equipped to engage in these types of protracted, heavy-handed regulatory endeavours.

55 See Van Rooijen, supra n 110, 18.

156 This matter is not over, and is currently subject to litigation before the General Court.

157 Ibid. Finally, it may well be the case that the company has not kept the information necessary to interoperate, as often software companies do not document well their technological innovations (object and source code). 
(v) Misconception No 5

Allegations of abusive failure to disclose interoperability information are often overly broad, and request the disclosure of information that goes beyond the interface specifications strictly necessary to interoperate. It will often be the case that not all of the dominant firm's technology and product design information would have to be disclosed to ensure interoperability. ${ }^{158}$ Courts and agencies should restrict the scope of any disclosure order to the strict minimum, and avoid mandating the disclosure of information protected by IP rights unless it has been shown that such disclosure is essential to ensure interoperability. ${ }^{159}$

\section{Tying}

\section{(a) Introductory Remarks}

The integration of complementary products, frequent in technology-enabled markets, makes them particularly prone to allegations of unlawful tying. This is nowhere more evident than with software, in respect of which integration is often costless, as illustrated by the two investigations launched by the Commission against Microsoft in the past decade. As the CFI recognised in Microsoft I,

"The IT and communications industry is an industry in constant and rapid evolution, so that what initially appear to be separate products may subsequently be regarded as forming a single product, both from the technological aspect and from the aspect of the competition rules." 160

Following the GC's Microsoft I ruling, the legal standard under which allegations of unlawful tying will be assessed appears to be well established. Tying will be deemed abusive if four cumulative conditions are satisfied: ${ }^{161}$

158 As noted by a Commission official in an Article following the IBM 1984 undertaking:

"the U/T did not oblige IBM to disclose product design information. This was acceptable to the Commission which throughout the formal proceedings had argued that interface specifications do not reveal the design of the products concerned. As the U/T did not oblige IBM to disclose product design information it would not seem to have removed IBM' $\mathrm{s}$ incentives to improve its products and to offer the best ones available in the marketplace because if IBM succeeded in doing that customers would address themselves to IBM. The U/T therefore not only stimulated competition in that it removed a major obstacle for IBM's competitors to offer innovative System/370 products at an earlier moment in time than they could have done in the absence of the $\mathrm{U} / \mathrm{T}$, if at all, but also because of this reinforced competition it put pressure on IBM to innovate and improve upon its own products".

See Lomholt, supra n 118, 10.

159 Not all interoperability information is protected by IPRs, especially in the software industry. Courts should apply the Magill and IMS Health standards to cases involving IPRs, and rely on the lesser Brönner standard for non-IP protected interface information.

160 See Microsoft, supra n 123, para 914.

161 Ibid, para 844. 
1. first, the tying and tied products are two separate products;

2. secondly, the undertaking concerned is dominant in the market for the tying product;

3. thirdly, the undertaking concerned does not give customers a choice to obtain the tying product without the tied product; and

4. fourthly, the practice in question forecloses competition. ${ }^{162}$

The interpretation of the second and fourth conditions does not raise particular issues in technology-enabled markets. By contrast, the notion of "separate products" contained in the first condition, and the element of coercion required by the third condition are fertile grounds for debate. ${ }^{163}$

\section{(b) Separate Products}

In its Guidance Paper, the Commission states that

"Whether the products will be considered by the Commission to be distinct depends on customer demand. Two products are distinct if, in the absence of tying or bundling, a substantial number of customers would purchase or would have purchased the tying product without also buying the tied product from the same supplier, thereby allowing stand-alone production for both the tying and the tied product." 164

The Commission thus appears to recognise that two products will be considered separate for the purposes of a tying claim only if there is separate consumer demand for both the tying and the tied product. The existence of separate customer demand for the tied product alone would merely represent a necessary, but not a sufficient, condition. There should also be separate demand for the tying product. In addition, the reference to "stand-alone production" should be interpreted as meaning stand-alone production for which there is customer demand. ${ }^{165}$

Unfortunately, the Guidance Paper then goes on to state that "evidence that two products are distinct could include . . . indirect evidence, such as the presence on the market of undertakings specialised in the manufacture or sale of the tied product without the tying product". This seems to contradict

162 Ibid, para 842.

163 On tying law see, eg I Lianos, "Tying and Bundling as a Leveraging Concern under EC Competition Law" (2009) 1 World Competition 144; S Liebowitz and S Margolis, "Bundles of Joy: The Ubiquity and Efficiency of Bundles in New Technology Markets" (2009) 1 fournal of Competition Law Ë Economics 1.

164 See Guidance on the Commission's enforcement priorities in applying Article 82, supra n 69, para 51.

165 This view appears to be confirmed by the Technology Transfer Guidelines, where the Commission states that for tying to occur, "it is a condition that the products and technologies involved are distinct in the sense that there is distinct demand for each of the products and technologies forming part of the bundle". See Commission Notice-Guidelines on the application of Article 81 of the EG Treaty to technology transfer agreements [2004] OJ C101/2, para 191 . 
the initial assertion that it is necessary to establish the existence of separate demand for the tying product alone, and has the potential to lead to absurd results, especially in technology products. It is perfectly possible for there to be separate demand for the tied product without the tying product, but no separate demand for the tying product without the tied product. In particular, as products evolve to include new functionalities (sometimes in the hundreds), it is often the case that there will remain for some time stand-alone demand for, and production of, the tied product despite the fact that consumers will no longer purchase the allegedly tying product without the allegedly tied functionality. For instance, consumer demand for a device that kept track of contact details, meetings and the like used to be satisfied by what was known as a personal digital assistant (PDA). Over time, mobile telephones began to integrate those functions, and nowadays it is unlikely that there is independent consumer demand for a smartphone without those functionalities-despite the fact that there may remain demand for, and a stand-alone supply of, such PDAs.

\section{(c) Coercion}

As noted above, a finding of abusive tying presupposes that the dominant firm does not give its customers the option of obtaining the tying product without the tied product. ${ }^{166}$ Put simply, the dominant firm must coerce customers wishing to purchase the tying product into also purchasing the tied product. In the Microsoft I case, the Commission and the GC found clear evidence that Microsoft had coerced customers that required Windows - suppliers of PCs into also obtaining Windows Media Player (WMP). That finding hinged on the fact that Microsoft only supplied a version of Windows that included a preinstalled WMP-Microsoft did not offer Windows without WMP. ${ }^{167}$ The GC held that the fact that consumers were unable to acquire the tying product without simultaneously acquiring the tied product was sufficient for it to be satisfied that there had been coercion. ${ }^{168}$

As a matter of economics, the problem with coercion is twofold. First, coercion may result in customers of the dominant firm acquiring supplementary products which they do not need at all. For instance, a customer may not need a warranty for a new PC but be forced to purchase one because the manufacturer does not sell PGs without such a warranty. In antitrust terms, this would be an issue of exploitation. Secondly, coercion may restrict the customer's freedom to choose between different supplementary products which

166 See Microsoft, supra n 123, para 955. Customers must be deprived of the "realistic choice of buying the tying product without the tied product".

167 Ibid, para 946.

168 Ibid, para 961. 
it does need to acquire. ${ }^{169}$ As a result of coercion, the customer is automatically directed to, or locked into, the dominant firm's tied product at the expense of rival products. In antitrust terms, this would be an issue of exclusion. Customers who must take the tied products supplied by the dominant firm forego resources (eg money, space) which could be allocated to substitute products supplied by competitors. In Hilti, the Commission found that the tying of nail cartridge strips used in nail guns and nails was abusive. ${ }^{170}$ Customers who had been compelled to acquire the dominant firm's (tied) nails were held to have foregone their freedom of choice regarding the source of supply of those nails which, in turn, resulted in the exclusion of independent nail suppliers. Importantly, this type of coercion can only arise if the tied product is a rivalrous good or, in other words, a product whose acquisition prevents or limits the acquisition of other, substitutable, products (notably those offered by rivals). ${ }^{171}$

In technology-enabled markets, and in particular with regard to information goods such as software and internet-based services, however, the exploitative or exclusionary consequences of coercion will often not occur. That is because many of those products are not rivalrous in consumption (eg because they are supplied free of charge, or because space constraints are non-existent).

Viewed under this light, the Commission's tying decisions against Microsoft are wrong. In those cases, Microsoft's customers could not have been coerced because media players and internet browsers are non-rivalrous goods which are distributed for free. ${ }^{172}$ Due to the possibility of multi-homing, ie the ability for customers to acquire, install and use several internet browsers/media players on a single PC, ${ }^{173}$ the freedom of choice of Microsoft's customers was never undermined. In addition, from a technical perspective, the limited file size

169 The rulings of the EU courts in Hoffmann-La Roche and Hilti cast light on this issue. The judgments of the Community courts are replete with references to the fact that coercion entails a restriction of customers' freedom of choice. In Hoffmann-La Roche, for instance, the ECJ held that the dominant firm tied its customer in a way to "[d] eprive the purchaser or restrict his possible choice of sources of supply and to deny other products access to the market" (Hoffmann-La Roche, supra n 45, para 60).

170 See Eurofix-Bauco [1988] L65/19.

171 We slightly stretch the classic definition of a rivalrous good. Traditionally, rivalry relates to a situation where "Everyone technically can use the good, but the use of the good by one person detracts from the ability of others to enjoy the good". See J Taylor and A Weerapana, Economics (South-Western College Publication, 6th edn, 2009), 435. We shift from a situation where the use of one good limits the ability of another person to use that same good, to a situation where the use of one good limits the ability of that same person to use another good.

172 On its side, the Commission stated that monetary sacrifice was not a requirement for the establishment of a tying abuse because "the wording of paragraph (d) of Article 82 does not include a reference to "paying" when introducing the element of a 'supplemental' obligation". See Microsoft, supra n 23, para 831. This brings some perspective with the General Court's odd assertion that consumers had to pay an extra fee for WMP included in the total price of the Windows OS. See Microsoft Corp v Commission, supra n 123, paras 967-68.

173 See J Tirole, "The Analysis of Tying Cases: A Primer" (2005) 1 Competition Policy International 12 : 
of most internet browsers and media players, as well as the development of cloud computing, meant that the volume of hard disk space required to store additional software became increasingly trivial.

Of course, it could be argued that, rather than end-users, Microsoft had in fact coerced OEMs (PC manufacturers) to purchase a bundle comprising WMP and Internet Explorer. Those OEMs, however, were not subject to any sort of technical coercion, given that Windows worked perfectly with rival internet browsers and media players. Moreover, there was no contractual coercion, because OEMs remained free to change the default settings on PGs and install rival software programs.

The Microsoft decisions thus appear to be inconsistent with conventional tying law founded on traditional industrial organisation considerations. On closer examination, these decisions show how behavioural economics can be used to construe novel theories of harm. Behavioural economics suggests that dominant firms may leverage market power absent coercion simply by exploiting customers' biases. ${ }^{174}$ In the Microsoft decisions, the Commission found that the pre-installation of WMP and Internet Explorer on Windows was conducive to leveraging because of "end-users' inertia". ${ }^{175}$ The Commission argued that users did not switch to rival software products which they could easily and freely download because they faced obstacles such as searching, choosing and installing a competing software application, which could stem from a lack of technical skills which users could not overcome. ${ }^{176}$ In Microsoft II, the Commission relied on empirical analyses to confirm its findings. A consumer survey showed that a majority of users $(51 \%)$ had not downloaded alternative browsers.

"[ $[\mathrm{n}$ a two-sided market in which the cost of multi-homing for users facing the tie is small, the tie on that side of the market need not preclude competitors from profitably competing, even when competitors' technology is undifferentiated from the tied technology from their point of view".

See also J Gabszewicz and X Wauthy, "Two-Sided Markets and Price Competition with Multihoming", mimeo (Université Catholique de Louvain, 2004), available at http://ideas.repec.org/p/ cor/louvco/2004030.html. In a multi-homing market, there is a priori no reason why a buyer should choose to acquire a single product only, at the exclusion of the other.

174 See M Bennett, J Fingleton, A Fletcher, L Hurley and D Ruck, "What Does Behavioral Economics Mean for Competition Policy?" (2010) 1 Competition Policy International 121:

"Behavioral economics suggests that even small switching costs can have significant effects on consumer behavior in the presence of consumer inertia, endowment effects, and default bias. This can, in turn, make foreclosure more likely to occur through tying and bundling."

According to behavioural economics, dominant firms may also leverage market power absent coercion, simply by exploiting customers' intrinsic biases, such as inertia, hassle costs, availability heuristics and risk aversion.

175 See Microsoft, supra n 23, para 870.

176 Ibid, paras 866, 869 and 870; Case COMP/39.530 Microsoft (tying) [2010] OJ C36/7, para 48. 
Because demand in technology-enabled markets often consists of end-users, it is possible that behavioural economics will be found attractive by antitrust courts and agencies. However, theories such as the ones put forward by the Commission in the Microsoft cases are, in our view, dangerous. First, they are based on empirical surveys of user behaviour, which gives rise to "framing" concerns (in other words, concerns that the results will be affected by how questions are asked). ${ }^{177}$ Secondly, the use of behavioural theories of harm raises a more fundamental issue, which can be described as one of imputability (or, in economists' jargon, an identification problem). ${ }^{178}$ This can be illustrated by the cases against Microsoft, which in essence were not so much about a dominant firm seeking to abusively coerce customers as about those customers' inability to make optimal choices due to their own intrinsic biases. One may question the appropriateness of laying the blame exclusively on the dominant firm in a case where any foreclosure of rivals is due to customers' lack of interest in the products themselves. By way of comparison, in other concentrated sectors, such as retail banking, where the degree of competition is weak due to consumer switching rigidities, competition authorities have cautiously refrained from sanctioning companies through recourse to the competition rules. Rather, other instruments (such as consumer law) are used to foster the mobility of retail banking customers. ${ }^{179}$

\section{Predatory Pricing ${ }^{180}$}

A plethora of technology-enabled products/services are given away for free by their suppliers. The ICT sector offers countless illustrations of this phenomenon. Email services, video and musical content (eg youtube.com, dailymotion.com), news (eg most newspapers websites), horizontal web-searching services (eg google.com and bing.com), vertical web-searching services (eg travel tickets searches), social network accounts (eg Facebook, Linkedin and Twitter profiles), software and applications of all sorts (eg video games, office tools), data storage

177 People provide different answers when the same questions are presented in different ways. See A Tversky and D Kahneman, "The Framing of Decisions and the Psychology of Choice" (1981) 4481 Science 453; M Salinger, "Behavioral Economics, Consumer Protection and Antitrust" (2010) 1 Competition Policy International 71.

178 On this see N Petit and N Neyrinck, "Back to Microsoft I and II: Tying and the Art of Secret Magic" (2011) 2 Journal of European Competition Law \& Practice 117. On legal grounds, competition rules target firms' misconduct in the market place.

179 If nudging customers may be the sole solution to open markets, consumer law may be a more appropriate tool than competition law to achieve that aim. See E Garcès, "The Impact of Behavioral Economics on Consumer and Competition Policies" (2010) 1 Competition Policy International 150, which stresses that remedial interventions may generate inefficiencies.

180 A number of papers have also alluded to other non-price predation strategies in innovation markets, such as the introduction of genuine innovations to harm rivals, and predatory systems' rivalry strategies that seek to introduce product systems incompatible with those of rivals. See J Ordover and R Willig, "An Economic Definition of Predation: Pricing and Product Innovation" (1981) 91 Tale Law fournal 8. 
services (eg dropbox.com), blogging platforms (eg Typepad, Wordpress) etc are all provided to users for free.

From a competition law standpoint, free products look, on their face, suspicious. After all, a dominant supplier who gives away products for free seemingly engages in the worst possible form of predatory pricing (a worse form of predation may possibly consist in paying customers to purchase, a practice that can be labelled "negative pricing"). For each product/service supplied, the price tag is zero. Without even considering this pricing policy under the $A K Z O^{181}$ benchmarks (in particular, the rule that prices below average variable costs are presumably unlawful), ${ }^{182}$ one can jump to the conclusion that the dominant firm necessarily incurs a loss on every unit sold. Such sacrifice could be seen as irrational and likely, under traditional antitrust analysis, to foreclose as-efficient rivals. ${ }^{183}$

Such an application of the conventional predatory pricing framework to the ICT sector would be overly simplistic. The fact that no price is charged to consumers does not mean that no price is charged at all, or that none of the dominant firm's costs are recouped. In two-sided markets the price of the service offered to customers present on one side of the market is charged to customers present on the other side of the market, and costs are recovered in that way. For instance, Facebook's social network services are offered for free to their users because Facebook generates revenue from advertisers that place display advertisements on Facebook's web properties. ${ }^{184}$ This business model is not specific to technology-enabled markets. Many bricks-and-mortar companies also rely on two-sided monetisation techniques. For instance, some daily newspapers are given away for free because they rely entirely on advertising. More generally, cross-subsidisation in conglomerate firms (where certain customer segments finance the purchases made by other segments) or the provision of public goods by the state (where some taxpayers finance part of the benefits provided to others) respond to the same logic. Two-sided markets, however, are more common in the high-tech field. That said, not all technology-enabled markets are two-sided. Most hardware products (eg computers, chipsets), for instance, are paid for by their direct users.

181 Supra n 37, para 71.

182 As apparently refined in Post Danmark, supra n 60. For first comments on this decision see S Barazza, "Post Danmark: The CJEU Calls for an Effect-based Assessment of Pricing Policies" (2012) 3 Fournal of European Competition Law E Practice 466; R Subiotto and D Little "The Application of Article 102 TFEU by the European Commission and the European Courts" (2012) 3 Journal of European Competition Law \& Practice 175.

183 See Guidance on the Commission's enforcement priorities in applying Article 82, supra n 69, para 63.

184 On the difficult assessment of the relevant market for online advertising see J Ratliff and D Rubinfeld, "Online Advertising: Defining Relevant Markets" (2010) 3 Journal of Competition Law E Economics 653. 
Moreover, the fact that no price is charged for a particular service does not mean that no price will be charged to all customers. Often, in technology-enabled markets, firms resort to so-called product/service versioning: ${ }^{185}$ customers will only pay a price if they use certain premium services with additional features (eg LinkedIn Business, Business Plus and Executive profiles). The basic service is offered for free as a sample, demo or loss-leader to entice users to discover the service and, in turn, induce them to migrate to the high-end service (a common business practice in computer programs, video games, etc). As noted by Chris Anderson, the author of the bestselling book The Long Tail:

"One of the most common business models on the internet, from Skype to Yahoo! Mail, is to attract lots of users with a free service and convince some of them to upgrade to a subscription-based 'premium' one that adds higher quality or better features. Because digital services are cheap to offer, the free customers cost the company so little that it can afford to convert only a tiny fraction of them to paying customers." 186

In this context, courts and agencies may fail to understand the basic characteristics of certain technology-enabled markets, and mistakenly uphold allegations of unlawful abuse. The recent Bottin Cartographes/Google France, Google Inc case provides a striking illustration of this. The case concerned the Google Maps API, ${ }^{187}$ a bundle of applications licensed for free to companies willing to embed Google maps on their websites. More precisely, companies that use the Google Maps API can offer a string of services on their websites, such as the Geocoding web service (finding latitudes and longitudes on a Google map), the Directions web service (finding itineraries on a Google map), the Distance web service (estimating the length of journeys with Google maps) and Street View images.

A French company which until then had sold competing online mapping services, Bottin Cartographes, brought proceedings against Google. The main allegation was that the zero pricing of the Google Maps API was predatory and therefore in violation of the French rules on abuse of dominance. In a somewhat nonsensical judgment, the Court of Commerce of Paris upheld Bottin Cartographes' claim. ${ }^{188}$ It held that the sale price of the Google Maps API was "equal to 0" and could thus not allow Google to recoup any of the production costs inevitably incurred by Google for the provision of such services. Moreover, those costs, which primarily consist of those incurred for obtaining "the rights for the geographic data (or aerial views)", were likely to be

185 See H Varian, "Versioning Information Goods", paper prepared for Digital Information and Intellectual Property, Harvard University, 23-25 January 1997, available at http://people. ischool.berkeley.edu/ hal/Papers/version.pdf.

186 See C Anderson, The Long Tail (Hyperion, 2006), 223.

187 Application Programming Interface. The case was not about the general Google Maps "portal" or the paid-for product "Google Maps API Premier".

188 See Tribunal de commerce de Paris, 15ème chambre, Jugement du 31 janvier 2012, Bottin Cartographes Google France, Google Inc. 
high, given that "Google, due to its global coverage, must aggregate data from several dozen suppliers". ${ }^{189}$ The Court further found that this had not only led to the elimination of all competitors on the market (although the Court cites only one such competitor, Maporama, whilst Bottin remained present in the market), but "was evidently part of a wider exclusionary strategy". In language redolent of conspiracy theories, the Court stated that, from the start, Google had sought to pursue the hidden goal of displaying targeted advertising on maps placed on firms' websites, with a view to basically milking advertisers.

There are good reasons to consider that the Court got it wrong in the light of the specific business model at play in the relevant market. ${ }^{190}$ How, indeed, could the Court assert that Google would not recoup its costs with its free licensing policy while acknowledging that advertisers would bear the brunt of this policy through prices charged for targeted advertising? In saying this, the Court unwittingly highlighted the existence of a classic two-sided effect - that the Google Maps API provided for free to companies was simply financed by advertisers - yet entirely overlooked it.

The Court could have just paid a short visit to Google's website to understand that the provision of the Google Maps API for free is also a classic example of versioning (see Fig 3). Google only gives away the basic version of Google Maps API for free. Companies wishing to offer more functionality to visitors of their website can purchase Google Maps API for business, which is licensed under specific financial conditions. To a certain extent, the price charged for Google Maps API for business thus finances the "free" offering of Google Maps API.

The analysis above should sound a note of caution for courts and agencies dealing with allegations of predatory pricing on technology-enabled markets. First, low or zero prices should generally be deemed to benefit consumersthey are the essence of a perfect competitive process. ${ }^{191}$ Secondly, any price-cost analysis of predatory abuse allegations should be based on the price charged either to indirect users in the case of multi-sided markets or on the price charged for other products in the case of versioning.

189 Here, the Court's analysis is again misguided. Those costs are fixed costs that Google should normally not try to recoup in the short run, and which in turn have no bearing on prices.

190 Somewhat more worryingly, the Court of Commerce seemed to ignore the basic principles of the law on abuse. For instance, it observed that the objective of eventually exploiting advertisers was an "exclusionary strategy", which it is not.

191 Moreover, if products/services are given away for free, this means that financial switching costs are likely to be extremely low, as consumers will make no sunk investment into a product or service. 


\section{Google Maps API licensing}

\section{Compare your Google Map API options}

Google Maps API

The Google Maps APIs let you embed Google Maps in your web pages or mobile apps.

Your service must be freely and publicly accessible to end users.

Learn more about the licensing terms for each API in the documentation, or by following the links below.

Google Maps API for Business

Google Maps API for Business provides enhanced features and added support to organizations who are adding maps to their fee-based websites or mobile apps, or to their internal websites.

Contact a Google Maps API for Business representative

\begin{tabular}{|c|c|c|}
\hline Features & Maps API & Maps API for Business \\
\hline Street View & $\checkmark$ & $\checkmark$ \\
\hline Geocoding Web Service & 2500 requests per day & $100 \square 000$ requests per day \\
\hline Directions Web Service & $\begin{array}{l}2500 \text { requests per day with } \\
10 \text { waypoints per request }\end{array}$ & $\begin{array}{l}100 \square 000 \text { requests per day with } \\
23 \text { waypoints per request }\end{array}$ \\
\hline Distance Matrix Web Service & $\begin{array}{l}100 \text { elements per query } \\
100 \text { elements per } 10 \text { seconds } \\
2500 \text { elements per day }\end{array}$ & $\begin{array}{l}625 \text { elements per query } \\
1000 \text { elements per } 10 \text { seconds } \\
100 \square 000 \text { elements per day }\end{array}$ \\
\hline Elevation Web Service & $\begin{array}{l}2500 \text { requests per day with } \\
25 \square 000 \text { samples per day }\end{array}$ & $\begin{array}{l}100 \square 000 \text { requests per day with } \\
1 \square 000 \square 000 \text { samples per day }\end{array}$ \\
\hline $\begin{array}{l}\text { Static Maps API maximum } \\
\text { resolution }\end{array}$ & $640 \times 640$ & $2048 \times 2048$ \\
\hline Static Maps API maximum scale & $2 X$ & $4 X$ \\
\hline $\begin{array}{l}\text { Street View Image API maximum } \\
\text { resolution }\end{array}$ & $640 \times 640$ & $2048 \times 2048$ \\
\hline Analytics & & $\checkmark$ \\
\hline Demographics Layer & & $\checkmark$ \\
\hline Support & |Maps API & Maps API for Business \\
\hline $\begin{array}{l}\text { Google Maps API Developer } \\
\text { resources }\end{array}$ & $\checkmark$ & $\checkmark$ \\
\hline Service Level Agreement & & $\checkmark$ \\
\hline Technical Support & & $\checkmark$ \\
\hline Support portal \& usage reporting & & $\checkmark$ \\
\hline Use cases & Maps API & Maps API for Business \\
\hline Free \& publicly available & $\checkmark$ & $\checkmark$ \\
\hline Internal deployments & & $\checkmark$ \\
\hline $\begin{array}{l}\text { Embedding in software and } \\
\text { applications for fee }\end{array}$ & & $\checkmark$ \\
\hline Reselling services with Google Maps & & $\checkmark$ \\
\hline Control of advertising & & $\checkmark$ \\
\hline Private asset tracking & & $\checkmark$ \\
\hline
\end{tabular}

Fig 3 Google Maps API Licensing 


\section{Price Discrimination}

Price discrimination is a natural pricing strategy in technology-enabled markets. ${ }^{192}$ As noted by Chris Anderson, a rule of good business in ICT markets is that one price does not fit all. ${ }^{193}$ Three main reasons are often advanced to explain why price discrimination is a pervasive strategy in such markets. First, it is very common for technology-enabled markets to exhibit high (or constant) fixed costs and low (or zero) marginal costs. ${ }^{194}$ Given that technology suppliers are not capacity constrained, they have incentives to price discriminate in order to sell as many units as possible because each unit sold above marginal cost contributes to the recovery of fixed cost. ${ }^{195}$ This logic works both for information goods (eg media content) and physical goods (eg chipsets).

Secondly, the very features of ICTs make it exponentially easier for suppliers to charge customised prices for similar goods/services, based on customer behaviour, characteristics, location, etc. Information technologies such as clickstream tracking, ${ }^{196}$ online registration, cookies and privacy settings ${ }^{197}$ enable "fine grained observation and analysis of consumer behaviour". ${ }^{198}$ Amazon, for instance, has been reported to offer CDs and books at different prices, based on the clickstream pattern of visitors. ${ }^{199}$ Similarly, information technologies entitle the widespread and timely use of individualised pricing techniques such as auctions and yield management. ${ }^{200}$ For instance, eBay combines both by offering similar products through auctions (at low prices, but with uncertainty)

192 See Anderson, supra n 186, 211.

193 Ibid.

194 See Varian et al, supra n 12.

195 The situation is different in non-technology markets, where there are capacity constraints. In those markets, fixed cost recovery does not take the form of output maximisation practices, but is achieved through value maximisation strategies on the range of supplies that can be produced.

196 See Forbes, "I Got it Cheaper than You", available at http://www.forbes.com/ forbes/1998/1102/6210082a_print.html:

"software that lets a Web-based merchant such as Amazon.com identify individual visitors to its Web site. Then the software studies a Web-surfer's "clickstream" - the way that person navigates through the Web site. Based on that behaviour, the software can instantaneously target the shoppers for specific products and prices. If that visitor behaves like a price-sensitive shopper - perhaps by comparing many different products without buying - he may be offered a lower price".

197 See Y Chen, "Oligopoly Price Discrimination by Purchase History" in Fredenberg and Strand, supra n 74119.

198 See Varian et al, supra n 12, 12.

199 See J McGuigan, R Moyer and F Harris, Managerial Economics (South-Western College Publications, 1998).

200 Yield management may be described as a method for managing capacity profitably in order to maximise yield or profits from a fixed resource. For instance, regarding airline seats, yield management often involves overbooking. S Kimes, "A Strategic Approach to Yield Management" in A Ingold, U McMahon-Beattie and I Yeoman (eds), Field Management. Strategies for the Service Industries (Thomson, 2nd edn, 2000), 2; S Kimes and R Chase, "The Strategic Levers of Yield Management" (1998) 2 Journal of Service Research 156. 
or under the "Buy It Now" system (higher prices). ${ }^{201}$ A somewhat less well known example is that of Radiohead. In 2007, the rock band offered its latest LP, In Rainbows, online for whatever individual users wanted to pay. ${ }^{202}$

Thirdly, many of those markets are component markets, where users purchase combinations of individual components rather than a pre-assembled, homogeneous end-product. Dell, who popularised the sale of online-customised computers to customers, offers a topical example of this in relation to physical goods. ${ }^{203}$ Similarly, consumers of information goods often purchase microchunks of data. ${ }^{204}$ For instance, music users will typically not purchase a full LP but, rather, download a range of titles from competing bands, across music styles. In the same vein, readers of online newspapers almost never read a full journal issue but, rather, purchase a variety of articles of interest to them. As a result, most of those customers end up with an individualised product, which can be subject to a specific price tag. Last but not least, suppliers of information goods enjoy a greater ability to offer similar products/services in different versions, packages and formats, and to charge distinct prices for them. For instance, Yahoo! has been reported to offer 20-minutes-delayed stock prices for free and real-time stock quotes for $\$ 9.95$ per month. This form of versioning, which is widespread in the software industry, is from an economic standpoint ${ }^{205}$ akin to price discrimination.

It is obvious that the observed ubiquity of price discrimination in technologyenabled markets has the potential to bring it into conflict with the Article 102(c) TFEU stipulation that it is abusive for a dominant firm to "appl[y] dissimilar conditions to equivalent transactions with other trading parties, thereby placing them at a competitive disadvantage". Nevertheless, we believe that the enforcement of Article 102(c) TFEU in technology-enabled markets should remain at best limited. This viewpoint is anchored in the wording of the Treaty itself. First, Article 102(c) TFEU requires that the differential pricing scheme leads to the application of distinct prices to "equivalent transactions". Although it casts little light on this concept, the ECJ's case law suggests that two transactions are equivalent if they cover goods or services which, from the customer's perspective, constitute functional and geographic substitutes for each other. In other

201 See Anderson, supra n 186, 221.

202 See the website http://www.mavaru.com/, which has fully endorsed the "pay for what it's worth" business model for the distribution of online music.

203 See Varian et al, supra n 12, 13, referring to this as "mass customization" or "personalization".

204 See Anderson, supra n 186, 220.

205 See Varian, supra n 185, 1:

"the point of versioning is to get the consumers to sort themselves into different groups according to their willingness to pay. Consumers with high willingness to pay choose one version, while consumers with lower willingness to pay choose a different version. The producer chooses the versions so as to induce the consumers to "self-select" into appropriate categories." 
words, two (or more) transactions are equivalent if they relate to two (or more) goods or services that belong to the same market. As such, the Article 102(c) TFEU prohibition should not apply to widespread practices, such as product customisation, versioning or yield management, whose very existence demonstrates, in and of itself, that they are not viewed as substitutes by customers.

Secondly, another reason that leads us to believe that the application of Article 102(c) TFEU should remain limited in technology-enabled markets is that this provision does not catch conduct targeted at end-users in retail market segments, where price discrimination appears to be the most pervasive in technology-enabled markets (at least if we rely on the amount of economic literature devoted to price discrimination on such segments as a proxy). The wording of Article 102(c) TFEU only prohibits practices that place "trading parties" at a "competitive disadvantage". But, end-users are not trading parties who can entertain competitive relations amongst themselves. Hence, they cannot suffer from any competitive disadvantage vis-à-vis each other within the meaning of Article 102(c) TFEU.

Likewise, discriminatory price cuts that harm the dominant firm's direct competitors (primary-line injury price discrimination), rather than its trading parties (secondary-line injury price discrimination) should not be caught by the prohibition of Article 102(c) TFEU. Of course, the old case law of the ECJ has occasionally disregarded the Treaty wording by finding unlawful primaryline injury price discrimination (eg in Hoffmann-La Roche, ${ }^{206}$ Michelin $I^{207}$ and Irish Sugar $\left.{ }^{208}\right),{ }^{209}$ but this decisional stream has dried out in recent years.

In fact, the requirement that the pricing practice puts one (or more) firm(s) at a competitive disadvantage seems to restrict the scope of application of Article 102(c) TFEU to markets where a vertically integrated firm has a subsidiary that it seeks to favour over downstream rivals. ${ }^{210}$ This finding has been corroborated by scholars. Swanson and Baumol, for instance, consider that risks of anticompetitive price discrimination are more plausible in market settings involving vertically integrated firms, and possibly IPR holders. ${ }^{211}$ In contrast,

206 See Hoffmann-La Roche, supra $\mathrm{n} 45$.

207 See Nederlandsche Banden Industrie Michelin, supra n 105.

208 See Case T-228/97 Irish Sugar plc v Commission [1999] ECR II-2969.

209 On this strand of case law see, eg D Geradin and N Petit, "Price Discrimination under EC Competition Law: Another Antitrust Doctrine in Search of Limiting Principles?" (2006) 2 Journal of Competition Law and Economics 479; M Armstrong, "Price Discrimination", MRPA paper (October 2006), available at http://eprints.ucl.ac.uk/14500/1/14500.pdf; R Inderst and T Valletti, "Price Discrimination in Input Markets" (2009) 1 The RAND fournal of Economics 1.

210 It could also be argued that, similarly to excessive prices, a finding of abuse under Art 102 TFEU seems possible only if the upstream firm holds an input that is "indispensable" within the meaning of the case law. Otherwise, the dominant firm can lawfully refuse to supply. It would be nonsensical to condemn such a dominant firm for abusive discrimination against rivals, whilst deeming it free to harm those very same rivals by withholding supplies.

21 See D Swanson and W Baumol, "Reasonable and Nondiscriminatory (RAND) Royalties, Standards Selection, and Control of Market Power" (2005) 1 Antitrust Law fournal 26. 
whilst theoretically possible from a legal standpoint, secondary-line injury price discrimination by a non-integrated dominant firm seems implausible from an economic standpoint (for instance, a pure IP licensor). No dominant seller ever has any incentives to distort downstream competition on pain of undermining: (i) competition for the distribution of its products/services; and/or (ii) its own market power.

Interestingly, despite a paucity of precedents, the Commission's biggest pending case in a technology-enabled market revolves around issues of abusive secondary-line injury discrimination. ${ }^{212}$ In the ongoing investigation against Google, the main theory of harm under consideration appears to be that Google manipulates the natural results returned by its general search engine to grant preferential placement to links pointing to its own related vertical search services at the expense of rivals. ${ }^{213}$ Vertical search engines are search engines that focus on a specific segment of online content, eg comparison-shopping websites (also called shopbots), travel search engines ${ }^{214}$ and restaurant search engines. ${ }^{215}$ Google controls several such engines - eg Google Flight Search, Google News, Google Product Search, Google Scholar - from which it derives significant advertisement revenues.

Google's alleged placing of its own vertical search sites on top of ranking results would create a competitive disadvantage for its rivals because users would be driven towards Google's vertical search engines rather than towards as-efficient rival ones. ${ }^{216}$ A figure commonly cited is that the first three links displayed

212 Google was also condemned (upon interim relief) in France for abusive discrimination. See Autorité de la concurrence's Press Release, "Following the Interim Measures Issued by the Autorité de la concurrence last June, Google Commits to Modify in a More Transparent and Predictable Way for Advertisers the Rules Governing its Online Advertising Service, AdWords", 28 October 2010, available at http://www.autoritedelaconcurrence.fr/user/standard.php?id_ rub=368\&id_article $=1488$.

213 As explained by Commissioner Almunia:

"First, in its general search results on the web, Google displays links to its own vertical search services. Vertical search services are specialised search engines which focus on specific topics, such as for example restaurants, news or products. Alongside its general search service, Google also operates several vertical search services of this kind in competition with other players. In its general search results, Google displays links to its own vertical search services differently than it does for links to competitors. We are concerned that this may result in preferential treatment compared to those of competing services, which may be hurt as a consequence" (emphasis added).

See "Statement of Vice-President Almunia on the Google Antitrust Investigation", supran 25. The allegation in the EU seems to focus on natural search results, and abusive manipulation of the algorithm, while in the US, the investigation seems also concerned with increases in the prices of ad rates for competitors.

214 Expedia and TripAdvisor are parties to the proceedings.

215 These vertical search engines are the ones that generate the highest revenues.

216 Whilst empirical studies abound on the correlation between search results and clicking rates, and reach distinct results, most stress the common feature that the top three search results garner a large majority of clicks. Results displayed on the second page attract a comparatively marginal number of clicks. 
on a search engine get approximately $80 \%$ of the traffic. This practice would allow Google to demote rival vertical search engines in its search ranking. Without user clicks, those rival search engines would lose search accuracy, and would eventually be forced off the market because of their inability to generate good search results. ${ }^{217}$ Of course, users remain at any rate free to directly visit a vertical search portal. As is often argued by Google, competition is just "one click away". ${ }^{218}$ Yet it seems that $90 \%$ of users do not directly use vertical search engines. ${ }^{219}$ They appear to begin by conducting so-called "meta searches" in general search engines (for instance, a trip from Brussels to Papeete), and only subsequently click on links towards vertical search engines (that would lead them, for instance, to a specialised travel search engine).

At this stage, the outcome of the Google investigation remains unclear.

\section{Abusive Litigation}

Theories of harm based on abusive litigation have not, to the best of our knowledge, featured prominently in cases brought by the Commission over the last several decades. This has changed in recent months, as the Commission has launched, in quick succession, formal investigations into Samsung's ${ }^{220}$ and Motorola's ${ }^{21}$ enforcement of their respective SEPs. Judging from the content of the Commission's press releases, it seems that the Commission is considering whether the mere act, by a holder of SEPs (who has committed to license them on FRAND terms), of seeking injunctive relief against an unlicensed implementer of that standard constitutes an abuse of a dominant position:

"Following complaints by Apple and Microsoft, the Commission will investigate, in particular, whether by seeking and enforcing injunctions against Apple's and Microsoft's flagship products such as iPhone, iPad, Windows and Xbox on the basis of patents it had declared essential to produce standard-compliant products, Motorola has failed to honour its irrevocable commitments made to standard-setting organisations. In these commitments, Motorola engaged to license those standard-essential patents on fair, reasonable and non-discriminatory (FRAND) terms. The Commission will examine whether Motorola's behaviour amounts to an abuse of a dominant market position prohibited by Article 102 of the Treaty on the Functioning of the EU (TFEU)."

217 A search engine - in this context, a vertical search engine-needs to run a minimum scale of searches on a daily basis to be efficient. It needs in particular to investigate the searching pattern of users on their search engine (where they go, how they click, etc). To achieve statistically significant results, this investigation must be implemented using a sufficiently sizeable cohort of users. Here again, therefore, size matters for search engines' accuracy.

218 For a critical appraisal of this assertion see C Argenton and J Prüfer, "Search Engine Competition with Network Externalities" (2012) 1 Journal of Competition Law \& Economics 73.

219 Only a very narrow category of internet users have preferred sites to which they go directly.

220 See Commission Press Release, "Commission Opens Proceedings against Samsung”, supra n 82.

221 See Commission Press Release, "Commission Opens Proceedings against Motorola", supra n 83. 
While the press releases announcing these investigations do not explain the Commission's approach in any detail, some insight into its current thinking can be gained from its Decision of 13 February 2012 approving Google Inc's acquisition of Motorola Mobility. In considering whether Google would have an incentive, following the proposed acquisition, to prevent third parties from gaining access to its SEPs in an anticompetitive manner, the Commission stated: ${ }^{222}$

"106. [A]ny company manufacturing products incorporating a certain standard must either obtain the appropriate licences covering the technology included in that standard or risk infringing the IP rights of the patent holders' reading on the standardised technology. In the event licensing discussions fail, the SEP holder may ultimately take its counterparty to court and seek an injunction ...;

107. Depending on the circumstances, it may be that the threat of an injunction, the seeking of an injunction or indeed the actual enforcement of an injunction granted against a good faith licensee, may significantly impede effective competition by, for example, forcing the potential licensee into agreeing to potentially onerous licensing terms which it would otherwise not have agreed to . . . To the extent that injunctions are actually enforced, this furthermore may have a direct negative effect on consumers if products are excluded from the market. Even if exclusion of competing products from the market through injunctions were to be temporary (ie. there would be a delay only in access to the relevant products until the counter-party of the SEP holder agreed to the commercial terms demanded), in a fast-moving market such as the smart mobile device market, serious harm could potentially be caused by it." ${ }^{\prime 23}$

This Decision therefore appears to suggest that an SEP holder who has given a FRAND commitment and then threatens to seek, seeks or enforces an injunction on the basis of its SEPs could, in some circumstances, be regarded as abusing a dominant position in a relevant market.

This reading appears to have been confirmed by the Commission's press release announcing the adoption of a Statement of Objections against Samsung:

"The European Commission has informed Samsung of its preliminary view that Samsung's seeking of injunctions against Apple in various Member States on the basis of its mobile phone standard-essential patents ('SEPs') amounts to an abuse of a dominant position prohibited by EU antitrust rules. While recourse to injunctions is a possible remedy for patent infringements, such conduct may be abusive where SEPs are concerned and the potential licensee is willing to negotiate a licence on Fair, Reasonable and Non-Discriminatory (so-called "FRAND") terms."

222 See Google/Motorola Mobility, supra n 50.

223 Ibid, para 107.

224 See Commission Press Release, "Commission Sends Statement of Objections to Samsung on Potential Misuse of Mobile Phone Standard-Essential Patents," IP/12/1448, 21 December 2012, available at http://europa.eu/rapid/press-release_IP-12-1448_en.htm. 
To date, the EGJ has ruled only twice in cases of alleged abusive litigation. The first such case was ITT Promedia, ${ }^{225}$ a ruling in which the General Court (then the Court of First Instance) appeared to have de facto endorsed the legal standard, proposed by the Commission, that must be applied before a finding can be reached that judicial proceedings brought by a dominant firm constitute an abuse of that dominant position. ${ }^{226}$ That legal standard requires that two cumulative criteria be met:

"the action (i) cannot reasonably be considered as an attempt to establish the rights of the undertaking concerned and can therefore only serve to harass the opposite party; and

(ii) it is conceived in the framework of a plan whose goal is to eliminate competition." ${ }^{227}$

The Court went on to identify two key principles which must guide the Commission's assessment of any claim of abusive litigation. The first of those principles is that access to the Court, ie. the ability to ask a judge to protect one's rights, is itself a fundamental right, protected by quasi-constitutional rules, and therefore that the institution of legal proceedings will constitute an abuse "only in wholly exceptional circumstances":

"[T] he ability to assert one's rights through the courts and the judicial control which that entails constitute the expression of a general principle of law which underlies the constitutional traditions common to the Member States and which is also laid down in Articles 6 and 13 of the European Convention for the Protection of Human Rights and Fundamental Freedoms of 4 November 1950 . . A As access to the Court is a fundamental right and a general principle ensuring the rule of law, it is only in wholly exceptional circumstances that the fact that legal proceedings are brought is capable of constituting an abuse of a dominant position within the meaning of Article [102] of the Treaty." ${ }^{228}$

The second principle is that any exception to the right of access to the courts must be construed narrowly:

"[S]ince the two cumulative criteria constitute an exception to the general principle of access to the courts, which ensures the rule of law, they must be construed and applied strictly, in a manner which does not defeat the application of the general rule ...."229

225 See Case T-111/96 ITT Promedia NV v Commission [1998] ECR II-2937.

226 Ibid, paras 57-58. Despite statements to the contrary, in two previous paragraphs of its ruling, the Court had stated that there was "no need for it to rule on the correctness of the criteria chosen by the Commission in the contested decision" on the grounds that the applicant had "not challenge[d] the compatibility of those criteria as such with Article 86 of the Treaty". However, the Court then went on to examine whether the Commission's proposed criteria were satisfied.

227 Ibid, para 55.

228 Ibid, para 60.

229 Ibid, para 61. 
Almost 15 years elapsed before the Court was again asked to consider a claim of abusive litigation. In Protégé, ${ }^{230}$ the General Court unambiguously cast aside any doubts regarding the applicable legal standard by explicitly affirming the substance of the test proposed by the Commission in ITT Promedia. The facts in Protégé are as follows. The complainant alleged that Pernod Ricard SA had abused a dominant position in the market for Irish whiskey, in particular by bringing trademark opposition proceedings before the trademark offices of several European jurisdictions and the European trademark agency (OHIM) against the complainant's attempt to register several whiskey brands in order to delay its entry into the market. The Commission rejected the complaint on the grounds that it lacked sufficient Community interest to warrant further investigation. On appeal to the General Court, the Commission's decision was upheld. The Court reiterated that the Commission had a wide discretion as to whether or not to investigate complaints. ${ }^{231}$

Of significance for present purposes, in Protégé the General Court clarified the two cumulative criteria set out by the Commission in ITT Promedia, in particular by confirming that the first criterion contains, in reality, two limbs. The first limb requires proof that the action "cannot reasonably be considered as an attempt to establish the rights of the undertaking concerned" because it is manifestly objectively unreasonable or manifestly unfounded. The second limb appears to require separate proof that the action has no goal other than to harass the opposite party. ${ }^{232}$ In addition, the General Court reiterated that the two cumulative criteria must be applied restrictively, lest they undermine the general principle of access to the courts. ${ }^{233}$

Let us consider the Commission's recent investigations of Samsung and Motorola in the light of the legal principles set out in ITT Promedia ${ }^{234}$ as subsequently reaffirmed in Protégé (hereinafter the ITT Promedia test). The first hurdle the Commission will have to face will consist in showing that Samsung and Motorola occupy dominant positions. Contrary to the position adopted by some commentators, ownership of one SEP or a portfolio of SEPs does not necessarily confer dominance.

The fundamental elements of a claim for patent infringement are that: (i) the claimant owns the relevant patent(s) and they are valid; and (ii) the defendant has infringed or is likely to infringe the patent(s). However, in a

230 See Case T-119/09 Protégé International Ltd v European Commission, Judgment of the General Court of 13 September 2012 (not yet reported).

231 Ibid, paras 32-42.

232 Ibid, para 57: "The Commission rightfully considered that the objectively unreasonable character of the claim or the absence of legal ground that the claim must exhibit to be abusive was not manifest in casu" (our translation - no official English version available yet).

233 Ibid, para 49.

234 On this case, see also S Preece, "ITT Promedia v EC Commission: Establishing an Abuse of Predatory Litigation?" (1999) 2 European Competition Law Review 118. 
patent infringement action brought by an owner of SEPs, the existence of these elements appears to be the very essence of a finding of dominance. In other words, unless the patents are owned by the patentee, are valid and are infringed (because they are indeed essential to mandatory portions of the standard), then their ownership will not have conferred a dominant position on the patent holder and there can therefore be no claim that their exercise is abusive.

Assuming that the SEP holder is dominant, if the Commission were to proceed to the next step and apply the ITT Promedia legal standard, it would have to begin by asking whether a request for an injunction by an SEP holder who has given a FRAND commitment can reasonably be considered as an attempt to establish the patent owner's rights - or, conversely, whether it is manifest that such a request for an injunction is objectively unfounded and has no other goal than to harass the opposite party.

Given that the Commission's concerns relate to the role of the FRAND commitment made by the patent holder, the question then becomes: in which circumstances would the fact that a FRAND commitment was given by the SEP holder result in the request for an injunction being considered manifestly unfounded? In our view, a request for an injunction by an SEP holder who has given a FRAND commitment could only be deemed manifestly unfounded by reason of a failure to comply with such a FRAND commitment in the most exceptional of circumstances where the SEP holder could not have been unaware that the request for an injunction was baseless and would be rejected by the Court. This could conceivably be the case only where at least two cumulative conditions are met: (i) the SEP owner's failure to discharge its duties to negotiate in good faith in accordance with the FRAND commitment is manifest; and (ii) the implementer acted in a manner consistent with its duty to act in good faith and satisfied any other requirements provided under Member State law that must be met in order for an application for an injunction to be denied.

In our view, the first condition identified above (ie a manifest failure by the SEP owner to discharge its duties under the FRAND commitment) will be satisfied only in the limited circumstances where: (i) the patent holder refused to make any licensing offer or negotiate following an approach by an implementer; and (ii) the patent holder made an offer containing licensing terms so egregiously unreasonable that even on the most cursory of examinations a court could not fail to conclude that the patent owner was acting in manifest bad faith. A finding that the SEP owner's licensing proposal was merely unreasonable - or even highly unreasonable - or any court ruling denying the requested remedy, would not in itself be sufficient to satisfy the first limb of the ITT Promedia test. This is clear from, in particular, paragraph 57 of the Protégé judgment, which emphasised the requirement that the proceedings serve 
no purpose other than to harass the opposing party. By contrast, a finding by a court (including a preliminary finding) that the licensing terms offered by the SEP owner were not unreasonable, or a court decision granting the injunction applied for, should be considered conclusive evidence that the action was not manifestly unfounded.

Similarly, the second condition of the ITT Promedia test, ie that the proceedings form part of a plan to eliminate competition, is also likely to be particularly difficult for the Commission to demonstrate. It is clear, for example, that conduct by an SEP owner aimed merely at "forcing the potential licensee into agreeing to potentially onerous licensing terms which it would otherwise not have agreed to" or forcing "a holder of non-SEPs to cross-license those non-SEPs to it in return for a licence of the SEPs"- the two possibilities raised as the main competitive concerns regarding SEPs in the Commission's Google/ Motorola Decision ${ }^{235}$ - is not sufficient alone to satisfy the ITT Promedia standard. In other words, conduct designed merely to exploit a standards implementer, as opposed to excluding such an implementer from the market, cannot constitute abusive litigation. Moreover, the second condition of the ITT Promedia test makes clear that non-practising entities (pure licensors) that seek merely to license, and not implement, SEPs cannot be held guilty of abuse when they seek injunctions against SEP implementers as they are not in a competitive relationship with the latter. More importantly, perhaps, it would be irrational for an SEP holder to seek an injunction as part of a plan to eliminate competition. This is because a standards implementer can always expect to avoid an injunction by agreeing, or showing itself to be willing, to take a licence on FRAND terms, and no court in Europe will grant such an injunction without first being satisfied that the licensor has complied with its duty to offer a licence on FRAND terms.

These are high hurdles to overcome, and for good reason. The judicial choice of such a demanding legal standard for this type of abuse is predicated on the recognition that access to justice is a fundamental right, and as such can only be encroached upon in the most exceptional of circumstances. Moreover, from a public policy standpoint, a less stringent standard would have the potential to weaken the patent enforcement system which underpins the promotion of innovation. It should be noted that the analysis above applies strictly to the "abuse of litigation" claim, not to whether the patent owner should or should not obtain an injunction in the patent infringement proceedings it brought. These are mostly separate questions and should not be conflated. Courts are well equipped to deal with, and routinely grant or deny, requests for injunctions lodged by owners of essential as well as non-essential patents.

235 See Google/Motorola Mobility, supra n 50, para 107. 
Against this background, it is very worrying that, in its assessment of the Google/Motorola merger, the Commission appears to have reached the view that the possibility that an SEP owner will seek or secure an injunction could be anticompetitive without so much as a cursory examination of the cumulative conditions of the ITT Promedia test. ${ }^{236}$ In our view, any suggestion that such conduct by an SEP owner (regardless of whether he has given a FRAND commitment) can attract antitrust liability outside the very narrow circumstances set out in ITT Promedia or under a different legal standard would be ludicrous.

\section{G. Gonclusion}

We conclude with two observations, one on substance and the other on process.

First, whilst recent ECJ rulings show the Court's (and the Commission Legal Service's) almost complete unwillingness to abandon the obsolete form-based approach in the enforcement of Article 102 TFEU, the ever-increasing importance of markets belonging to the new economy makes the transition towards an effects-based approach more necessary than ever. An underestimated, and seldom mentioned, advantage of a clear endorsement of effects-based legal standards is that they would increase legal certainty and administrative efficiency. ${ }^{237}$ This is because the legal standards currently applied under Article 102 are too loose, often inconsistent and frequently arbitrary, while legal standards based on the effects of a course of conduct offer a coherent methodology, a set of well-defined and well-understood theories of anticompetitive harm, and a toolbox of specific evidentiary instruments.

Secondly, due to their dynamic nature, technology-enabled markets are often viewed as optimal candidates for quick-fix, rapid remedial intervention

236 Ibid, para 116:

"In conclusion, the Commission considers that Google is likely to have some ability posttransaction, in particular through seeking and enforcing injunctions, to significantly impede effective competition, including by potentially extracting onerous licensing terms from good faith potential licensees to which they would otherwise not have agreed, be it in respect of royalty levels or other licence terms (for example, the scope of the end products to which the licence must apply) or cross-licence."

See also paras 113, 115, 126-28.

237 See P Marsden, "Checks and Balances: European Competition Law and the Rule of Law" (2009) 22(1), Loyola Consumer Law Review 51, observing at 61 that:

"the reliance on more economics and balancing tests, like the rule of reason, may be what allows EU competition law to better accord with the rule of law. This can only happen, however, if judges are themselves able and willing to undertake more rigorous evaluation rather than rely on precedents that were never informed by economic analysis." 
by agencies and courts. ${ }^{238}$ This should be avoided, as the risk and cost of type I errors (false conviction) is significantly greater in those markets. Antitrust intervention in fast-moving sectors should not occur at an early stage of market development - ex post enforcement should remain the rule. By contrast, mature, slow-moving markets can be subject to a more ex ante approach, given that agencies are better able to predict their evolution and avoid regulatory mistakes. Even in sector-specific regulation, where ex ante intervention is the paradigm, the Commission recognises the perils of premature regulatory intervention:

"Newly emerging markets should not be subject to inappropriate obligations, even if there is a first mover advantage . . . Newly emerging markets are considered to comprise products or services, where, due to their novelty, it is very difficult to predict demand conditions or market entry and supply conditions, and consequently difficult to apply the three criteria. The purpose of not subjecting newly emerging markets to inappropriate obligations is to promote innovation . . ."239

Prudence, as opposed to precaution, should prevail.

238 See "Statement of Vice-President Almunia on the Google antitrust investigation", supra n 25:

"I believe that these fast-moving markets would particularly benefit from a quick resolution of the competition issues identified. Restoring competition swiftly to the benefit of users at an early stage is always preferable to lengthy proceedings, although these sometimes become indispensable to competition enforcement."

239 See Commission Recommendation of 17 December 2007, supra n 35, para 7. 